GEOLOGY OF MONTGOMERY COUNTY.

BY

ELSTON HOLMES LONSDALE. 



\title{
GEOLOGY OF MONTGOMERY COUNTY.
}

\author{
BY ELSTON HOLMES LONSDALE.
}

\section{CONTENTS.}

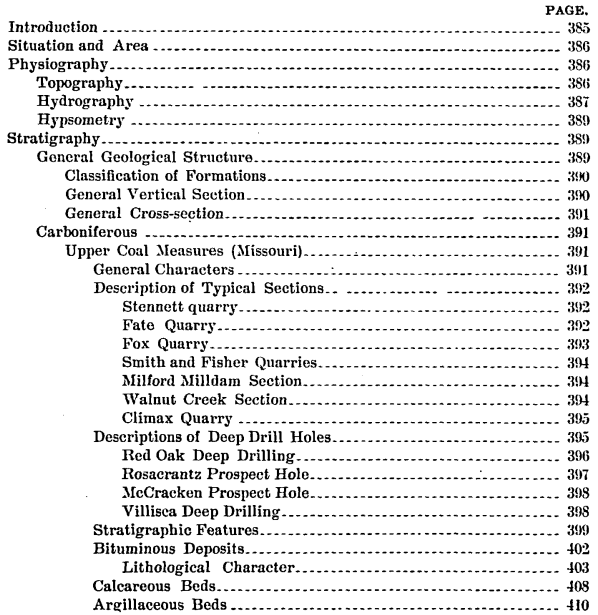




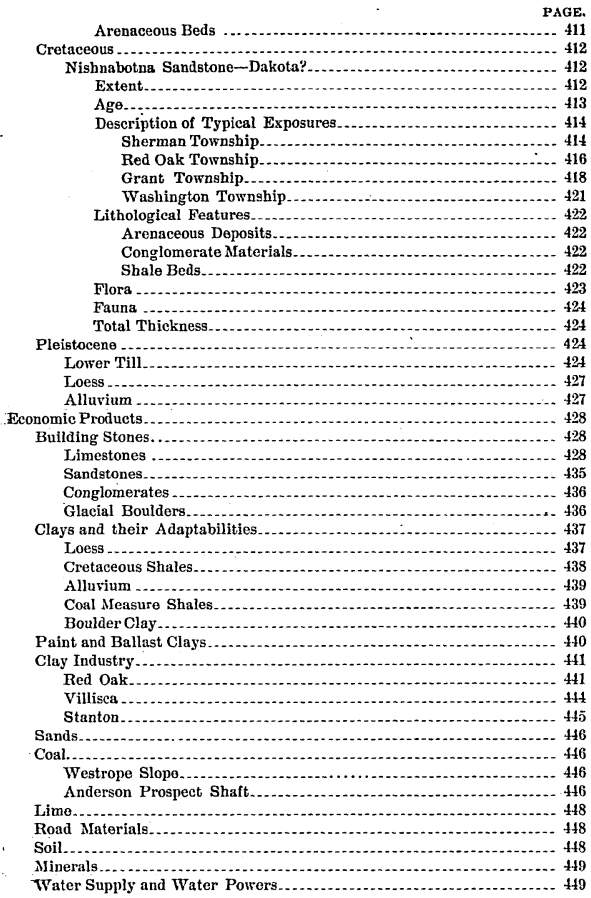




\section{INTRODUCTION.}

Early in 1867, a reconnoissance of the region lying between Des Moines, Iowa, and Nebraska City, Nebraska, was undertaken by Dr. C. A. White, State Geologist of Iowa, and Professor F. B. Meek of the United States Geological Survey. This preliminary survey was made at the instance of Dr. F. V. Hayden for two purposes: First, to connect the geological formations of Iowa with those in Nebraska, and, second, to trace out the coal beds in their western extension*.

Coal measure strata were found to cover the whole area between the Des Moines and the Missouri, and the conclusion was reached that the workable beds of coal are confined to the lower coal measures. The approximate depth at which they might be discovered by boring at Nebraska City was specified $\dot{f}$. The results of this geological reconnoissance in southwestern Iowa, so far as they pertain to Montgomery county, were published by Dr. White in 1868ł, but later they were elaborated and republished in 1870 s.

-Final Rept. of the U. S. Geol. Surv. of Nebriska, etc., p. 4. Washington, 1572.

tFirst Ann. Rept. of the U. S. Geol. Surv. of the Territories, etc., p. 7. Republished. Washington, 18 is. 1868.

$\$$ First and Second Ann. Repts. of Progress by the State Geologist, pp. 63-63. Des Moines,

sGeol. of lowa, vol. I. pp. 362-367. 18:0. 
At the time of this preliminary work the country was unsettled and facilities for such work were meagre, yet notwithstanding the unfayorable conditions under which the work was prosecuted the lithological characters and the geological age of the strata were, so far as general facts are concerned, accurately determined, and the correctness of the results has never been questioned.

Later, Aughey spent considerable time in this field and arrived at somewhat similar conclusions*. His results are noted on subsequent pages.

Since the time of the observations mentioned, certain changes in the conditions of the surface have taken place which make possible more detailed investigations. The grading for railroads, the changing of water courses, the boring of deep holes, together with the partial development of some of the upper beds, afford information which was before unobtainable.

\section{SITUATION AND AREA.}

Montgomery county lies in the southwestern quarter of the state. It corners on the southwest with Fremont, itself the extreme southwestern county. Between Montgomery county and the Iowa-Missouri line on the south and the Missouri river on the west, lie respectively, Page and Mills counties. The county is rectangular in shape and has a length of eighteen, and a width of twenty-four miles.

\section{PHYSIOGRAPHY.}

\section{TOPOGRAPHY.}

The upland of Montgomery county is a gently undulating plateau intersected by the rather shallow valleys of the larger water courses and their tributaries. The surface configuration is not marked by striking features. The entire district is, with a few exceptions, under a state of cultivation and only a few small upland areas which might be designated as unarable occur. The native forestry is confined almost exclusively to

-Phys. Geog. and Geol. of Neb., p. 163. 1880. 
the rough bottom along the streams. On the ridges a few patches of native prairie yet remain.

A profile run in an east and west direction shows a series of ridges and valleys lying nearly parallel and having an approximately north and south trend.

Next to the large streams there exists what is known as the first bottom, an area which is subject to overflow. Commonly it is waste land, but its areal extent is insignificent. Beyond this lowland rises the second bottom. Its general elevation above water level of the adjacent stream ranges from ten to thirty feet. It is classed with the first bottom as a terrace or flood plain. The declivity of the outer terrace is gradual, but sufficient for ample drainage. The total width of the lowland varies, ranging from a few hundred yards to perbaps two miles. It is distributed unequally and irregularly on the sides of the streams.

Commonly the slopes of the upland proper mergeimperceptibly into the outer margins of the upper flood plain, and the undulations along these slopes are of more or less regularity. Higher up, the sides of the ridges grade into the nearly level prairies or platean stretches, themselves well drained. In the northwestern townships these features are less prominent as a result of the absence of distinct drainage lines and the presence of a somewhat different superficial formation.

IIYDROGRAPHY.

From what has already been said it is seen that the natural drainage system of the county is nowhere incomplete. The accompanying sketch map, figure 46 , shows the courses of the principal waterways and their tributaries. Three streams traverse the entire length of the county and a fourth flows from near the northern border through the district. These are the East Nishnabotna, the West Nodaway, Walnut creek, and Middle Tarkio river. These large streams each receive numerous affluents. All the streams are tortuous. The waters flow first against the sloping bluffs on one side, then against those of the opposite, and the lengths of the courses are thus nearly doubled. 28 G Rep 
In general the valleys along the larger courses vary but little in areal extent and decrease in width but gradually toward the head waters. The larger streams are confined to channels not more than 200 or 250 feet in width, and are enclosed by banks rising ten or twenty feet above low water. They lie not

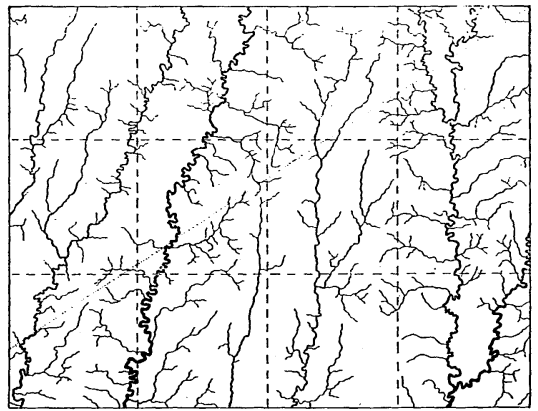

Figure 46. Sketch map of Hontgomery county showing drainage.

wholly in unconsolidated beds, for constant corrasion has cut . the channels as much as 100 feet below the upper stratified beds of the adjacent hills.

Concerning the age of these drainage basins there are certain features which, if considered alone would seem sufficient to fix the exact date when the work of corrasion began. Combined, the data afford conflicting evidences and render a classification difficult. In the first place the upland topography is not of the drift variety. Although present, the thickness of the drift is not great, and the preglacial cuttings were so deep that they practically determined the character of the postglacial relief. The hard limestones stand well above the water level of 
the streams and bear evidence of erosive action on an extensive scale. On the other hand the main beds of drift lie in place, almost exclusively over the upland bedded rocks. Hence, if ever deposited in the rock-bound valleys the drift has been later removed or altered beyond recognition as original deposits. Those beds which were laid down during the retreat of the ice after the work of extensive erosion had ceased must be excepted. Certainly there is evidence pointing to the fact that the valleys of the East Nishnabotna and of the Nodaways have been formed either in very early Pleistocene time or in the later Neocene. At all events they are very old. The smaller streams doubtless originated as the waters from the melting glaciers began to drain off freely.

\section{HYPSOMETRY.}

Little or no attention has been directed toward the relative altitudes of the various points in Montgomery county. The minimum elevation above sea level is approximately 960 feet. It is found at the exit of the East Nishnabotna. The probable maximum height is in Lincoln township, where the altitudes range from 1,250 to 1,375 feet above the sea level, and in extreme cases 300 feet above the base of the nearest valley. It may be that further eastward, between the valleys of the East Nishnabotna and West Nodaway river, the altitudes are as great as in Lincoln:township; for there is a noticable uniformity in the upland elevation. The altitudes of some of the railway points above sea level as given by Gannett, are as follows: Red Oak, 1,032; Villisca, 1,050; Coburg, 1,004; Hawthorne, 1,056. The slight amount of variation in the respective altitudes of the points mentioned is explained by the fact that they are all situated in or near the valleys.

\section{STRATIGRAPHY.}

\section{General Geological Structure.}

The unstratified rocks of Montgomery county belong to the Carboniferous and to the Cretaceous, while the unconsolidated materials above these belong to the Pleistocene. Along 
the water courses and some of their more important tributaries the bedded rocks crop out with sufficient frequency to afford some insight into the geological structure of the region. It is important, however, on account of the limited number of exposures and the distances respectively between them, to consider each outcrop somewhat carefully and critically. In addition, each boring must be studied, and conclusions must be drawn, not from individual sections, but from a compilation of all the information obtainable either in Montgomery county or in neighboring areas.

\section{OLASSIFICATION OF FORMATIONS.}

The following table indicates the divisions and the relations of the formations occurring in the county:

\begin{tabular}{|c|c|c|c|c|}
\hline GROUP. & SYSTEM. & SERIES. & STAGE. & SUB-STAGE. \\
\hline Cenozoic. & Pleistocene. & & & $\begin{array}{l}\text { Alluvium. } \\
\text { Loess. } \\
\text { Till. }\end{array}$ \\
\hline Mesozolc. & Cretaceous. & Upper. & Dakota; & Nishnabotna. \\
\hline Paleozoic. & Carboniferous. & Upper. & Missouri. & \\
\hline
\end{tabular}

General Vertical Section.-The exposed beds of Montgomery county have an aggregate thickness approximating 200 feet. This includes a thickness of perhaps seventy feet of unconsolidated beds. The perpendicular measurements given in plate $\mathbf{x}$ are not secured at a single point, but represent the combined thickness of the beds occurring above the lowest elevation within the district. 


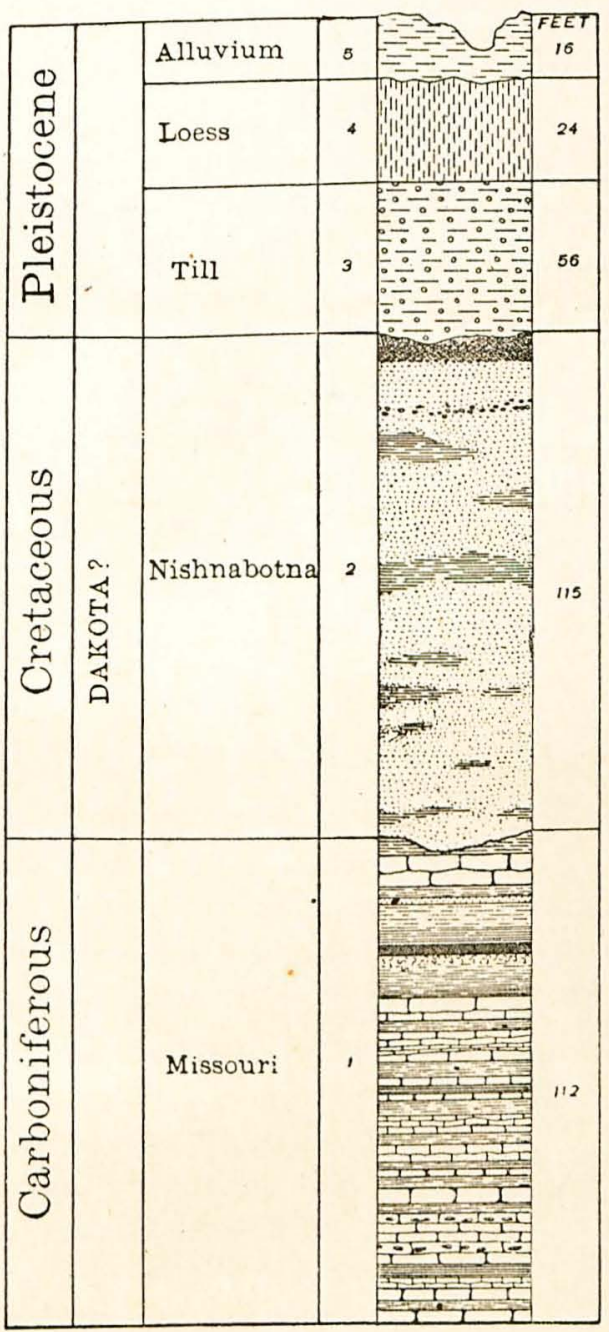

GENERAL SECTION OF GEOLOGICAL FORMATIONS IN MONTGOMERY COUNTY. 

General Cross-Section.-To further illustrate the relations of the several formations on the county figure 47 is inserted. With the exaggerated, vertical scale the principal features are fully brought out; the profiles and unconformities are shown. The section extends from the northeastern corner of the county, through Red Oak to the MillsMontgomery line. The coal seam near Milford appears to dip westwardly and at the same time becomes thinner. The upper six-inch seam, described in subsequent pages, dips similarly and must pass into bituminous shale, possibly before the center of the area is reached.

Geological Formations.

CARBONIFEROUS.

UpPer Carboniferous or CoAl Measures.

MISSOURI STAGE-UPPER COAL MEASURES.

The lowest rocks having surface exposures in the county belong to the Carboniferous system. They extend over the district, but are covered in part by the Cretaceous beds. Only the upper coal measures, or Missouri stage, is represented. It is the top rock of the lowlands and sometimes lies next to the drift in the hills. The measures can be traced almost the entire length of the county, both along the West Nodaway and the East Nishnabotna rivers and may be recognized along Walnut creek in the west-central and southern portions in the banks of Tarkio in the south-central, and of Middle Nodaway in the eastcentral, near the eastern boundary of the

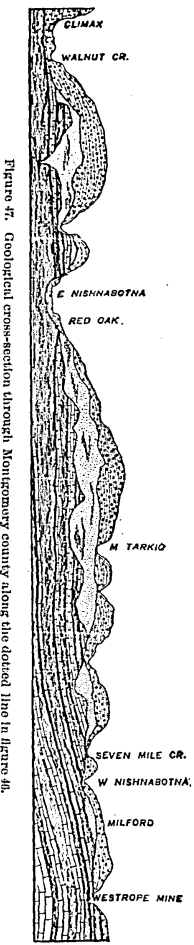


county. These exposures have perpendicular faces of from one or two, to thirty feet. Generally only a few ledges are visible.

General Characters.-The formation has been roughly eroded and its upper surface is furrowed with deep channels and depressions. A profile of this surface would be badly broken. The limestones withstand the action of weathering to a greater degree than the clay shales which are so characteristic of the same geological horizon farther east. Considering only the natural exposures in Montgomery county limestones seem to predominate, although argillaceous beds do occur in considerable thickness. However, a reference to the records of the deep holes which have been drilled in this, as well as in adjoining counties, shows the respective thickness of the limestones and shales to be just the reverse of what is the case in the greater number of the exposures. To illustrate the conditions mentioned a number of sections will be here inserted.

DESCRIPTION OF TYPICAL SECTIONS.

Stennett Quarry.-The following sequence is shown at the W. Stennett quarry on the Red Oak and Griswold branch railroad, just north of Stennett:

\begin{tabular}{|c|c|c|c|}
\hline 12. & Soil and loess & & INCHES. \\
\hline 11. & Clay, residuary, red to brown in color....... & 1 & 4 \\
\hline 10. & Limestone, weathered...................... & 2 & \\
\hline 9. & Shale, argillaceous...................... & & 7 \\
\hline 8. & 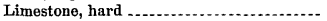 & 1 & 8 \\
\hline 7. & Shale, clayey, buff to grey & $\mathbf{3}$ & 7 \\
\hline 6. & Limestone, earthy, in part ocherous... & 2 & 6 \\
\hline 5. & Limestone, shaly & 3 & \\
\hline 4. & Limestone, impure, earthy............... & 1 & \\
\hline & Limestone, hard, sub-crystalline ..... & & 7 \\
\hline 2 & Limestone, contains much dark chert. & & 6 \\
\hline & & & \\
\hline
\end{tabular}

Number 8 is perhaps the most prominent ledge on either side of the river in this vicinity. Its character is persistent and being always a single ledge it serves well as a guide in connecting sections.

Fate Quairy.-Atthe Fate quarry (Tp.73 N., R. XXXVIII W., sec. 26, Se. qr., Ne. $\frac{1}{4}$ ) which lies across the river from Stennett, the prevalence of the hard beds is noticeable. Plate xi 


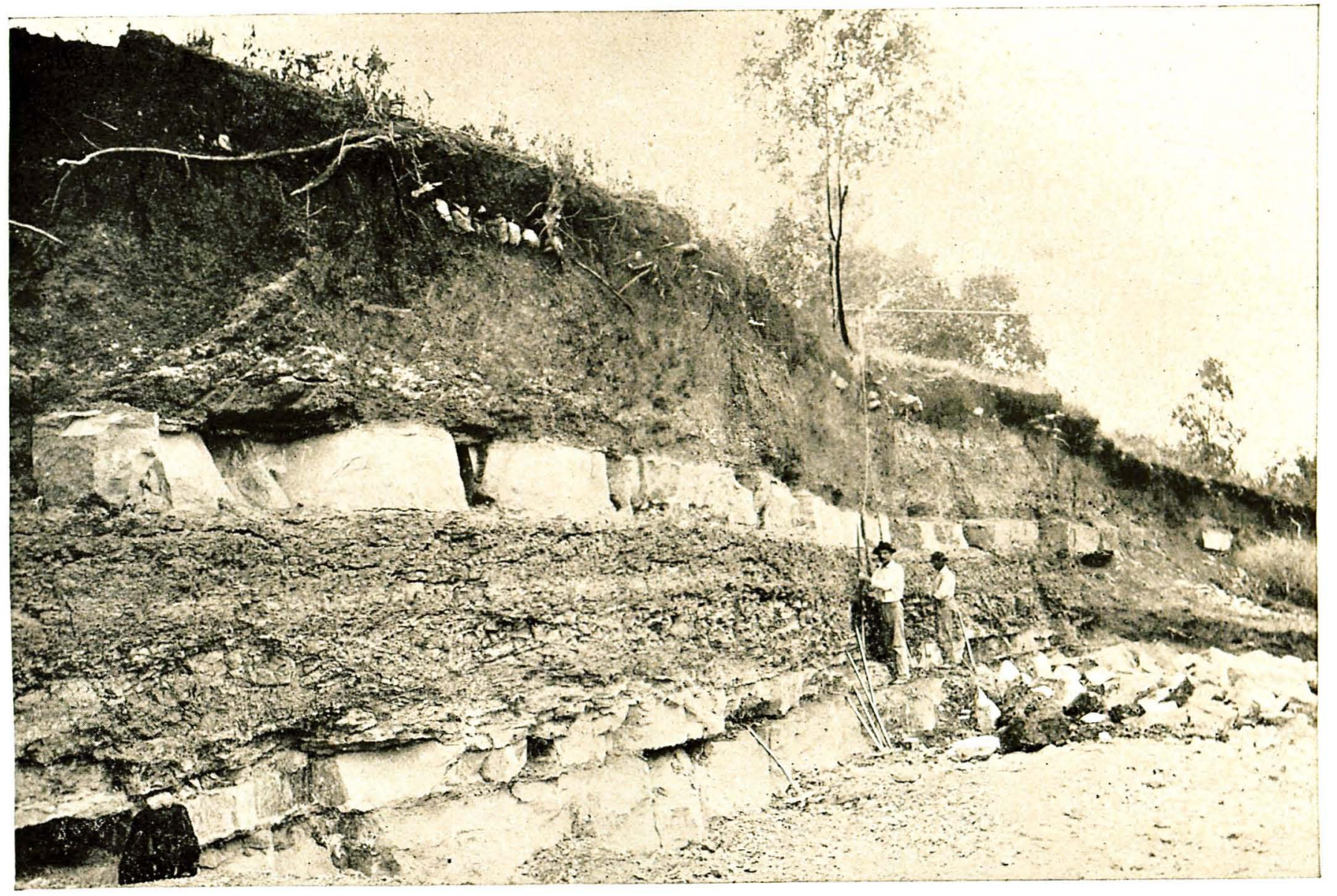

TYPICAL EXPOSURE OF THE MISSOURI STAGE OF THE COAL MEASURES; FATE QUARRY, STENNETT. 
shows the present quarry. The exposure at the old quarry is described as follows:

\begin{tabular}{|c|c|c|c|}
\hline & FEE & & INCHES. \\
\hline 16. & Limestone fragments in residuary clay ...... & $\overline{\mathbf{5}}$ & 6 \\
\hline 15. & 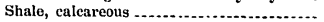 & & 6 \\
\hline 14. & Limestone, grayish, finc-textured...... & 1 & i \\
\hline 13. & Shale, argillaceous, buff to grey...... & 3 & 4 \\
\hline 12. & Limestone, earthy, flinty in upper part..... & 1 & 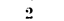 \\
\hline 11. & Limestone, texture coarse................... & 1 & \\
\hline 10. & $\begin{array}{l}\text { Limestone, upper two feet hard, lower part } \\
\text { earthy and bearing chert... }\end{array}$ & 2 & 8 \\
\hline 9. & Clay, buff ....................... & 1 & \\
\hline 8. & Limestone, "blue " ...................... & & 8 \\
\hline i. & Limestone, $t$-inch ledge, ehert in upper part & 1 & † \\
\hline 6. & 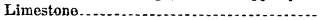 & 4 & \\
\hline 5. & Shale argillaceous, impure & & 2 \\
\hline 4. & Limestone, two ledges, both with chert...... & 2 & 2 \\
\hline 3. & Limestone, dark grey, soft $\ldots . . . . .$. & 1 & 5 \\
\hline 2. & Limestone, "blue" ....................... & 1 & 5 \\
\hline 1. & Shale, argillaceous . & 1 & 6 \\
\hline
\end{tabular}

Numbers 1 to 5 are not now exposed, but are known to occur as given, and the first of these is said to extend to the water of the river. At the mill a short distance down the stream it is seen resting on a bituminous shale. This shale is again shown in a sharp ravine about a quarter of a mile southward, and here the thickness is measured as sixteen inches. Along Pilot branch near the center of section 26, to the west of Stennett quarry, it is more than three feet thick and overlies two feet of shaly limestone which in turn rests on a hard fossiliferous limerock. The bituminous vein at this point is perhaps eight feet above the river, and in the ravine mentioned its elevation is about the same; indicating conclusively that the strata in this section have an appreciable dip to the north.

Fox Quarry.-Just a quarter of a mile north from the northeast corner of Montgomery county there is another good exposure of coal measure strata. This is at the Fox quarry on the south bank of the West Nodaway. The order of the beds is as follows:

FEET. INCHES.

11. Limestone, decomposed, and elay......... 2

10. Shale, argillaceous......................... t

9. Limestone, two ledges; calcite lined carities 


\begin{tabular}{|c|c|c|c|}
\hline 8 & Shale, calcareous, fossiliferous & T. & INCHES. \\
\hline 7. & Limestone, sub-erystalline ........ & 7 & 1 \\
\hline 6. & 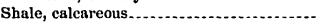 & & \\
\hline 5 & Limestone, brownish & & \\
\hline & $\begin{array}{l}\text { Shale, groy in upper part, black fissile at } \\
\text { bottom }\end{array}$ & 2 & 6 \\
\hline & Limestone, dark grey, coarse-textured.... & & 9 \\
\hline & $\begin{array}{l}\text { Shale, upper two-thirds red to grey; lower } \\
\text { portion brown to black, laminated....... }\end{array}$ & 2 & 1 \\
\hline & Limestone (partly exposed) & 1 & \\
\hline
\end{tabular}

The base of this section is probably twenty feet above the river at this point.

Smith and Fisher Quarries.-Near Milford in the extreme northeast portion of the county, the Carboniferous consists almost entirely of limestone in ledges from a few inches to more than three feet in thickness. Combining the outcrops shown at the Smith and the Fisher quarries, which are on opposite sides of the river, the following sequence is secured:

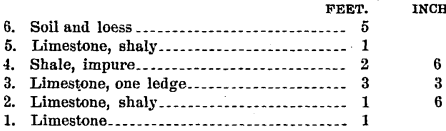

Milford Milldam.-At the milldam at Milford there are shown:

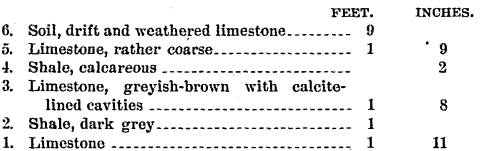

From these detailed sections the lithological characters of the uppermost rocks of the Missouri stage in the northeastern quarter of the county are shown to be in general quite similar to those noticeable in the central region.

Walnut Creek: Section.-In the northwest quarter of Montgomery there are no Carboniferous rocks in sight; the postglacial drainage not having cut through the drift. The most 
northwestern outcrop is along Walnut creek (Tp. 72 N., R. XXXIX W., sec. 1, Ne. qr., Se. $\frac{1}{4}$ ). The order of the division is here given:

FEET. INCHES.

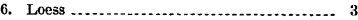

5. Limestone, weathered into thin layers..... 5

4. Limestone, grey to buff .................... 1

Limestone, thin layers.................................

2. Limestono, two ledges...................... 1 2

1. Limestone, "blue" -................. 1

Shales are here absent unless concealed by debris.

Climax Quarry.-Not far from the old village of Climax, at the extreme southwest, at the crossing of Walnut creek and the north line of section 30 of West township, a predominance. of the softer strata is noticeable. The section runs as follows:

\begin{tabular}{|c|c|c|c|}
\hline & FEF & & INCHES \\
\hline & Soil, boulder clay and sand.. & 1 & \\
\hline & Limestone, very fine-textured........ & 1 & \\
\hline & Shale, in part caleareous........... & 3 & \\
\hline & Shale, argillaceous... & 2 & 2 \\
\hline & Limestone, earthy & 1 & \\
\hline & Shale, dark grey... & 1 & \\
\hline & Limestone, earthy..... & 1 & 6 \\
\hline
\end{tabular}

In the south-central portion, along the banks of the Tarkio, both north and south of the Montgomery-Page county line, the coal measures are represented by limestones rather than argillaceous materials. Such is also the case at Corning, ten miles east of Montgomery county. The limestones here have a. total thickness of twelve feet. The bottom of the exposure is nearly on a level with the water in the East Nodaway river.

Summarizing the characteristics of the Upper Carboniferous beds in Montgomery county it may be said that sandstones are practically absent; shales occur in thin beds and limestones are prominent.

DESCRIPTION OF DEEP DRILL HOLES.

Since the visit of White and Meek* to this region deep drilling has been carried on at many points in search of coal or water. When expecting to fiud coal it has been customary to rely upon the theoretical estimates given by the authors mentioned. These attempts to locate coal seams have by no means

* U. S. Geol. Surv, of Territories, 136i, 1878, 1869. p. T. 1873. 
always resulted successfully. The churn, or slush drill has usually been employed and the records obtainable are not so satisfactory as where the core drill is used; yet it is not impossible to get an idea of the character of the strata from the churnings carefully preserved. It does not seem advisable to draw absolute conclusions from such data as to the thickness of a particular stratum, and at all times it is necessary that an allowance be made for inaccuracies liable to arise from a lack of care in the determination of the thickness and characters of each bed passed through.

From time to time holes have been put down in various sections of Montgomery county. These have varied in depth from that of the common surface well to 650 feet. The deepest borings have been prosecuted at Red Oak and Villisca.

Red Oak Drilling.-The record here given presents a somewhat condensed section of the Red Oak deep prospect hole*.

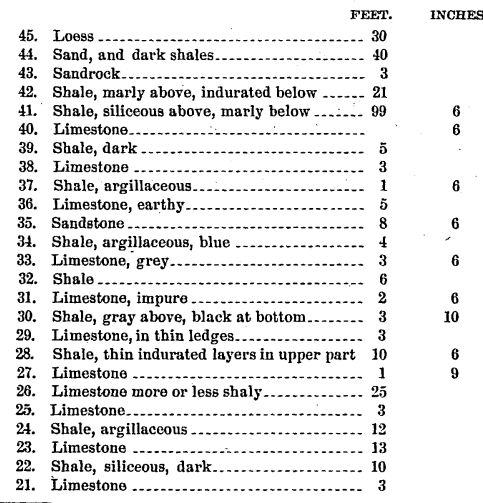

- Hist. Mont. Co. p. 422. 1881. 


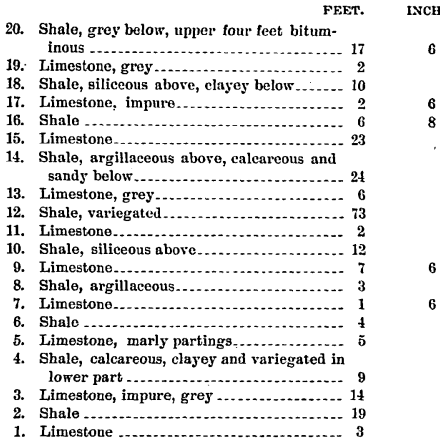

Numbers 42,43 and 44 of the above section are probably Cretaceous beds and all below these numbers certainly belong to the Missouri stage.

Rosacrantz Prospect Hole.-A deep hole was put down in Tp. 73 N., R. XXXVI W., sec. 31, Nw. qr., Se. $\frac{1}{4}$, to a depth of 230 feet. Carboniferous rocks were reached ninety feet below the surface under seventy feet of Cretaceous and twenty feet]jof Pleistocene. This is known as the Rosacrantz drilling. The record preserved is as follows:

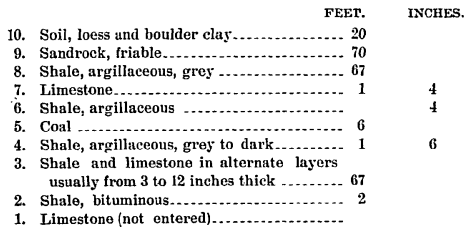


McCracken Deep Drilling.-In this same neighborhood, in -Tp. 75 N., R. XXXVII W., sec. 36, Nw. qr., Ne. $\frac{1}{4}$, another hole was bored in search of coal. The surface of the ground at this point is perhaps fifteen feet above a small tributary of Seven Mile creek. The section furnished of the McCracten drilling is here inserted.

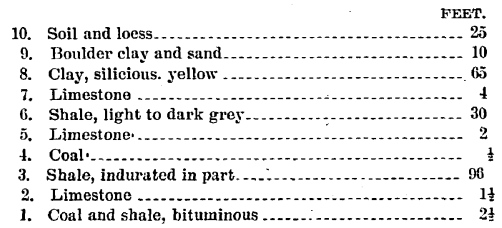

At this place the Carboniferous rocks lie next to the drift, the Cretaceous having been completely eroded. Number 1 was given as from two and one-half to four feet thick, and made up of coal, but other evidence would go to show that a considerable part of it is nothing more than bituminous shale, and that the coal is the Nodaway vein, of which mention will be made.

Villisca Prospect Hole.-No account was kept of the materials passed through in the well put down near Villisca (Tp. 71 N., R. XXXVI W., sec. 26, Ne. qr., Sw. 1) until the depth of 428 feet was reached. After that the following strata were met with:

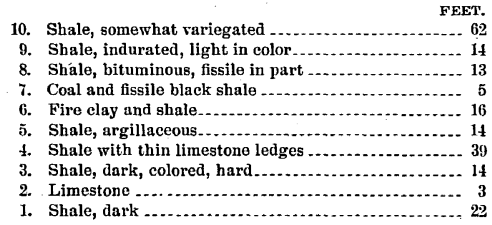

In this portion of the hole practically nothing but shales were encountered. 
The records presented show the character of the strata met with in sinking the principal drill holes in Montgomery county. Other shallower holes have been drilled, but the results show no conditions different from those displayed in the foregoing. They all show shales alternating with limestones, the shales in all cases predominating.

Considering these records as approximately correct there is nothing which would indicate that the upper coal measures have in any instance been passed through. The stratigraphic and lithological features are just such as mark the formation elsewhere.

STRATIGRAPHIC FEATURFS.

The earlier estimates of White and Meek are known to be more or less in error. In their reports on the region in question it was claimed that the upper and so-called middle coal measures of Iowa had an aggregate thickness of about 400 feet, a thickness less than the depth reached by some of the drill holes mentioned. These authors thought that the productive measures should be encounted in southwestern Iowa and points adjacent, at depths not to exceed 300 to 500 feet below the water level of the Missouri river at the southwest corner of Iowa. This level has an altitude of 907 feet above tide. The elevation of the East Nishnabotna at Red Oak is only about 100 feet above the plane. The same is true of the Nodaway at Villisca.

Supposing the Carboniferous strata in southwestern Iowa to be practically horizontal then it would not be necessary to go down more than the extreme estimate, 600 feet below the surface, at either Red Oak or Villisca before the lower coal measures would be reached. On the other hand it has been determined that the Paleozoic beds in this district are not level, but have a general dip towards the southwest. If the rate of decline be taken at the conservative and commonly accepted amount, ten feet per mile, the strata found at the surface at Red Oak, for instance, would be approximately 250 feet below water level at Nebraska City, which is about thirty-five miles distant. Assuming then this slope as actually existing, the 
depth to the lower coal measures at Red 0ak would not exceed 250 feet, still basing the conclusions upon the White-Meek estimates at the Missouri river.

The altitude of the top of the lower coal measures at Des Moines is about 850 feet higher than sea level. Low water mark at Red 0ak is about 1,000 feet above the same datum. Hence, allowing the same dip to the strata for the lineal distance between the two points, which is ninety-five miles, a perpendicular measurement of 1,100 feet would necessarily have to be gone through before the Des Moines rocks would be reached. This thickness would consist of nearly 1,000 feet of the upper coal measures, or Missouri stage with the remainder made up of the so-called middle coal measure now regarded provisionally as a part of the Des Moines stage*.

At Glenwood, Mills county, about twenty-five miles directly west of Red Oak, the corrected elevation of the railroad track is 980 feet above sea level. Several years ago, in the northwestern part of Glenwood at an elevation of 152 feet above the track, a well 2,000 feet deep was bored in search for water. Samples of the drillings were carefully taken and preserved by S. Dean. The section will not be inserted in full, but since what is true of the formation here applies equally to the lower rocks of Montgomery county, certain noticeable points brought out in the record may be mentioned. The recent examination of the drillings suggests a number of conclusions which differ very materially from those offered by Call $\dagger$.

The base of the upper coal measures was put by Call at 317 . feet from the surface. There is surely no sufficient reason for such a statement. The strata for a great distance below this limit are evidently not different in general character from those of the individual rocks which lie above. Beds of argillaceous shales alternating with layers of limestone extend to a depth of more than 1,400 feet below the surface. It would be more natural and consistent to set the limit of the upper measure in this drill hole at a depth of about 1,500 feet, and concede.

*Iowa Geol. Surv., vol. If. p. 120, 189.

+Proc. Iowa, Acad. Scl., vol. I, pt. 11, pp. 60-63. Des Molnes, 1892. 
the lower 500 feet to the Des Moines stage. A careful examination of the drillings below the upper coal measures as thus limited results in the finding of very fine-grained white to yellow sandstone with an occasional layer of common clay shales. Such materials extend to the bottom of the hole.

In Cass county, at Atlantic, thirty miles northeast of Red Oak, a well was bored to a depth of more than 1,300 feet. Down to 1,100 feet the rocks passed through consisted almost exclusively of the shales and limestone which are characteristic of the upper coal measures. Below that depth the materials were just such as appeared in the lowest 500 feet of the Glenwood well. The elevation at the Atlantic well is just a little above that of the surface at Glenwood. If the dip of the strata toward the southwest as given above is correct, this variation in the depth at which the sandrock formation was reached at the two localities would nearly be explained, the distance between the points being thirty miles.

Near Clarinda, twenty-five miles sontheast of Red 0ak, at an elevation of approximately 1,020 feet above sea level a well 1,002 feet deep was put down in the effort to ascertain if thick coal veins were present. It was shown that below the drift the entire thickness was almost wholly of shales and limestones. Here also it would appear that the upper coal measures were not passed through.

Prospecting has also been carried on at Shenandoah, twenty miles nearly south of the county seat of Montgomery county. A hole was bored 700 feet deep passing through shales and limestones only. At the Iowa school for the deaf near Council Bluffs, an 800-foot drill hole disclosed mainly argillaceous shales and hard limestones.

Results from investigations at other points might be given but with the data from the Red Oak and Villisca deep holes, in Montgomery county, and from several localities on the different sides of the district the structure is pretty well shown. These records, taken to depths of from 500 to 2,000 feet, reveal the character of the underground beds and counting upon the data as in a manner accurate the following conclusions are drawn: (1.) The combined thickness of the divisions of the 290 Rep 
upper Carboniferous in Montgomery county is in the neighborhood of 2,000 feet. (2.) The upper coal measures have a thickness in the same region of from 1,400 to 1,500 feet.

Broadhead,* in support of a similar opinion, records the upper coal measures in Atchison, the northwest county of Missouri, as more than 1,100 feet, and the upper Carboniferous as 1,900 feet in thickness. The estimate for the upper division has more recently been corroborated by Winslow. +

After briefly reviewing the Iowa-Nebraska coal field and the work of Meek and White in that territory together with that of Broadhead in Missouri, Aughey argues that the lower coal measures beds might be reached at any locality along the river from Omaha to Plattsmouth at the depth of from 800 to 900 feet below the surface. $f$ The information already given would certainly tend to prove that this opinion is not well founded.

BITUMINOUS DEPOSITS.

The position of Montgomery county, as well as of the entire southwest section of Iowa, with respect to points at which the mining of heavier veins of coal is carried on, is such as to make the finding of coal within the district very desirable. Prospecting has been prosecuted in a number of localities with widely varying results. These investigations were, as a rule, made at a time when the stratigraphic features of the coal measures were not understood; at a time when the horizontal and vertical extent of coal beds was counted upon as persistent through great belts of the formation.

In opposition to this view, Keyess suggests the conditions existing in other fields as equally prevalent in the Iowa measures. That is, instead of the one or two or three coal strata persistent throughout a large area, there are numerous separate beds which are disposed in lenticular basins of varying areal extent. This idea has later been accepted by Winslow $\|$ and has again been treated more fully by Keyes . Hence because

- Iron Ores and Coal Fields, Geol. Sur. of Mo., pt. Ji., pp. 6 and gs. 1873.

+Prelim. Rep. on Coal, Mlo. Geol. Sur., p. 23.1891.

† Phys. Geog. and Geol. of Nebraska, p. 166.1580 .

Aneriean Geologist, rol. X. p. 401, 1883.

IAnn. Rep. Geol. Sur. of Ark. for 1888. Prelim. Rept. on Coal, Mfo. Geol. Surr, pp. 37-38. 183

โCoal Deposits, Iowa Geol. Surv., vol II, p. 155, pl. xill. 189. 
heavy coal veins exist in certain sections, it is not to be inferred that corresponding veins will be found everywhere at the same horizon.

Lithological Character-Past investigations have failed to reveal the presence of heavy coal seams within the limits of Montgomery county. The attempt to locate coal beds of the lower coal measures has not been successful. If such veins do occur there is no evidence whatever pointing to the presence of any such thicknesses as are found in the same geological formation in central and southeastern Iowa and Missouri. In order to best understand the stratigraphic position and thickness of the bituminous layers within Nontgomery, the information afforded by the drill records in the county itself and in neighboring counties wherein coal has been reported, must be considered. But before doing this, reference will be made to the known occurrences of coal seams in the county under immediate consideration.

On the south bank of Williams branch (Tp. 73 N., R. XXXVI W., sec. 1, Se. qr., Sw. $\frac{1}{4}$ ) at the extreme northeast section of Montgomery county, a coal vein was discovered and mined about thirty years ago. The thickness of the layer varied from eighteen to twenty-two inches. White mentioned this occurrence but was inclined to treat it as one of little consequence and did not anticipate its becoming of any particular economic value*.

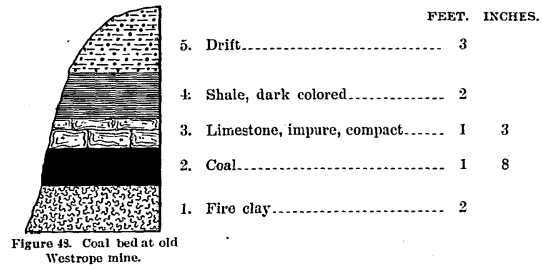

*Iowa Geol. Surv., First and Sec, Ann. Reports, p. 63. 1863. 
The latter development, however, was quite considerable in extent. Not only has the vein been mined at this point but at numerous others of which mention will be made hereafter. The appearance of this coal along the Nodaway river has given to the vein the name of Nodaway.

At the special locality referred to in the corner of Montgomery there are no good exposures of the vein or of the associated strata. The section shown in figure 4 represents the beds as they appeared at the time mining was in progress.

At Briscoe, three miles eastward, in Adams county, the Nodaway vein is mined from three or four shafts. The rocks at the localities in this immediate vicinity are similar to those formerly exposed on William's branch. The sequence as occurring at one of these shafts, the Plowman, is represented in figure 5. The uppermost twenty-five feet of material is drift.

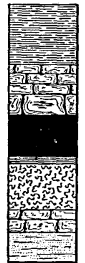

FEET. INCHES.

7. Shale, gray, clayey

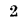

6. Limestone, gray 1

5. Coal........... 14

4. Shale, finely laminated, bitu-

minous ..... 3

3. Fire Clay ................ 1

2. Limestone, thin bedded........ $\quad 8$

1. Shale, sandy in part........... 1

Figure 49. Coal bed in Plowman shaft; Briscoe.

There are still other localities in Adams, Page, and Taylor counties where mining of this very persistent vein has been carried on for a period of several years. At Eureka and Carbon, between Villisca and Hawleyville, near New Market, near Shambaugh, and near Clarinda, coal mining is to-day an industry of considerable importance. From two to eight sliopes or shafts are now operated in each locality.

Further southward this Nodaway coal was found outcropcropping two miles north of the Iowa-Missouri line and Broadhead traces it to a point about fifteen miles into Missouri*.

\footnotetext{
-Iron Ores and Coal Fiel-1s, Mo. Geol. Sur., pp. 394-398. $187^{2}$
} 
The altitudes at the different places nearly correspond with that of the Nodaway river at the point least remote from the known occurrence.

From Briscoe to Quitman the lineal distance is approximately sixty miles. East of the line connecting these two points, except as already mentioned, there is no probability of the coal vein extending for any great distance. Limestones soon predominate and but rarely are the accompaning shales of much consequence. West of the line mentioned the presence of the vein is claimed at numerous points. In Tp. $72 \mathrm{~N}$., R. XXXVI W., sec. 33, Ne. qr., Se. $\frac{1}{1}$, coal was reported in a bored well at eighty feet from the surface. However, much credence is not put in this report since development, once begun, was given up before such a seam was reached.

In Page county (Tp. 70 N., R. XXXVIII W., sec. 24) at a point four miles south of Montgomery, a seam of coal supposed to be the Nodaway has been found, though with slightly less thickness than elsewhere. The only entirely certain occurrence of conl within Montgomery is the one mentioned in the northeast corner of the county. In all likelihood, however, this vein underlies at a greater or less depth a large portion of the district. In fact the eastern half, excepting possibly the region immediately adjacent to Villisca where erosion has been greater, likely bears the Nodaway vein within nogreat distance from the surface. It may be that in some instances the actual thickness of the coal is considerably less than the maximum found near Milford. It would seem that undulations exist in this region with the direction of the axis almost parallel to the direction of the generally supposed dip of the rocks. The trough of one of these undulations would cross somewhere in the western portion of Montgomery county.

It might be well to insert additional data relative to the Nodaway-coal which has been under consideration. From what has been definitely shown it will be seen that this seam extends under a greater territory than does any other yet found within Iowa, and the possibilities of finding it under a still larger area, especially westward and southward, seems favorable. 
In the western part of Fremont county the cropping out of a ten-inch vein of coal at an elevation of perhaps sixty feet above the Missouri bottoms is recorded by White*. He considered this to be an extension of the Nodaway coal, but in order to establish this fact additional field work is required. However, in case such proves to be a fact it may yet be practicable to connect the strata with the coal vein, which Meek describes as existing in Nemaha, Ote and Cass counties in Nebraska. Otherwise the Fremont exposure and those in Nebraska are probably of the same horizon, both wholly different from the Nodaway vein. About twenty miles in a northeasterly direction from the northeast corner of Montgomery county, at a depth of 262 feet, a coal seam with a thickness of from twenty to thirty-five inches has recently been discoveredt. In lithological character the strata overlying the coal at this point do not wholly conform to the features of the beds over the Nodaway seam.

Through a comparison of the relative thickness of the coal as shown in these several localities a more or less persistent and regular attenuation southwestward is noticeable.

The limited amount of attention given to the occurrences in southwestern Inwa does not allow the drawing of exact conclusions as to geographical extent and the continuity of the individual layers nor to their relative position. Careful field study over a large region is necessary. The estimates and theories are not offered as final settlement of the questions. There are weighty points in their favor and it is believed the suggestions may be relied upon.

As yet but the single vein of coal has been encountered above the water level in Montgomery county. Occasional outcroppings of black fissile shale, locally known as "coal blossom," give rise to the reports of additional seams.

In almost every record of deep drill holes in southwestern Iowa and adjacent fields coal is indicated. The distance of the strata from the surface of the ground ranges from a few feet to

*Am. Jour. Scl., (2), XLIV, p. 29.1867.

+Iowa Geol. Surv, vol. II, p. 4ł. 189. 
900 or 1,000 ; the thickness of the vein is given from a mere trace to five feet.

There stand out in this connection, two probable sources of error: (1.) Determination of the nature of the materials; (2.) Determination of the thickness of the individual beds. Errors from either of these sources are of common occurrence and usually arise from lack of care or non-appreciation of the importance of accurate work. The errors most probable which pertain to the lithological character are made up through the inability of persons in charge to distinguish limestone from sandstone or bituminous shale from coal. These mistakes have so often occurred that it is safe to believe that in certain instances where coal has been reported in the record, there was in reality nothing more than bituminous shale. A study of the surface rocks and of the reliable drill records confirms this belief. The tendency is naturally towards recognizing shale as coal. Hence, in the consideration of the reported existence of coal at the various localities, too much reliance must not be placed on the accuracy of records.

In the 560-foot prospect hole at Red Oak (see page 396) no coal was reported. Another hole, the Bolt and Crockett, was bored in section 32, south of Red Oak, and an eight-inch vein of coal was said to have been struck at a depth of about 100 feet. The elevation at the top of the hole is perhaps ten feet above the river at this point. Only a partial record of another drill hole at Red 0ak, at a point probably thirty feet above the elevation of the Nishnabotna was obtainable. More than one coal vein was said to have been passed through at depths between 200 and 300 feet. The greatest thickness of any of these was given as sixteen inches.

Upon comparison of the records a great diversity in the character of the strata at the three localities is evident. In the first case the hole was deepest but no coal was struck; in the last, only a few hundred feet distant, several veins were encountered. It is not improbable that shaly layers in the latter were mistaken for coal.

*IIIstory Montg. County, p. 420.1881. 
About two miles northeast of Red Oak is the Stockslager well, 125 feet deep. A few inches of coal are reported as occurring just under several feet of black shale at a depth of about ninety feet.

In Douglas, the northeastern township, in the sinking of the Rosacrantz prospect hole (see page 397) a six-inch vein of good coal was reported at a depth of 160 feet from the surface; none lower down. Westward, a little over a mile into Pilot Grove township, the McCracken boring recorded this same sixinch vein of coal at nearly 140 feet and another seam, doubtless the Nodaway, at a depth of 230 feet. The thickness of the latter was given positively as thirty inches. The McCracken drilling was started at an elevation somewhat less than that at the Rosacrantz and this explains the difference in the depth to the upper vein at the two localities as well as the appearance of the heavier vein in the one and not in the other. Other deep holes should discover this thicker vein.

The Lenz drilling was done in Tp. 73 N., R. XXXVI W., sec. 5 , Ne. qr., $\mathrm{Nw} \frac{1}{4}$. At 114 feet below the surface or eighty feet below the water of Rose creek, a seam of coal eight to twelve inches thick was met with. This is doubtless an attenuated portion of the Nodaway coal. Again near the southern boundary of Montgomery county (Tp. $71 \mathrm{~N}$., R. XXXVII W., sec. 33, Sw. qr., Ne. $\frac{1}{4}$ ), in prospecting for coal, J. W. Donaldson of Stanton, claims to have struck a thin vein, probably the Nodaway. This same vein is exposed at the abandoned Linquist mine about five miles southwest, in Page county.

Other reported occurrences of this seam or of other seams of coal in Montgomery county might here be recognized but more the accurate results of the drillings have been recorded already and these are deemed sufficient to indicate that while the presence of coal is evident the particular occurrences can not be satisfactorily correlated.

\section{Calcareous BEDS.}

The structure of the calcareous layers of the upper Carboniferous of Montgomery county has been already referred to in an incidental but general way in the discussion of the common 
character of the measures as a wholc. A more specific reference is scarcely necessary.

As has been shown, limestones made up the greater proportion of the upper or exposed rock, but the deep drilling has revealed that the shales predominate lower. In the general limestone formation the material separating the individual ledges usually has a thickness of but an inch or so, rarely so much as a foot. The thinner partings are themselves decidedly calcareous and are designated, where noted in the sections as marls. They may or may not bear fossils. Some of the partings have many species of shells in great abundance. In no case are these argillocalcareous layers of economic value.

The limestones may be arranged in three divisions, classed lithologically. (1.) Finely to coarsely textured, compact, and brittle; fossiliferous or non-fossiliferous. (2.) Finely textured, resembling number one but bearing chert. (3.) Earthy. The first and second classes make up nearly the entire calcareous division. They occur in weathered ledges frome one or two, to as many as forty inches in thickness. As a rule they bear fossils, but the extent to which they are fossiliferous varies greatly. In some of the ledges, such as are seen at the Stennett quarries and eastward, the characteristic species are so abundant and persistent as to enable the same strata to be traced for great distances merely thirough the recognition of the prevailing fossil forms.

The various ledges of limestone may be used for different purposes. The weathered, the thin, and the softer beds are adapted for road material, ballast or rubble. Others answer for rough masonry or for interior walls. The more solid, evenly textured rock is used for outside walls, sills, steps and for ornamental work. Some ledges that seem hard and compact when taken from the quarry are affected to such an extent by changing conditions or temperature and moisture as to make them almost valueless for onter constructional purposes. The greater number of the solid heavy beds of limestone are strong, durable, are easily dressed and admit of a superior finish. The heavier ledges which show no tendency to fracture, are used 
extensively as piers, abutments and foundations for bridge work and for milldams in the larger streams.

Chemical analyses of the limestones have not as yet been made, and the exact percentage of the carbonate contained is. not known. The composition of the rocks is certainly such as to warrant their use in the manufacture of lime. Years ago a white lime was burned at a number of localities within Montgomery county. In quality the product is said to have been good.

ARGILLACEOUS MATERIAL.

The clays of the upper Carboniferous are elsewhere in thestate of great value and are utilized in the manufacture of various kinds of wares including pottery, sewer-pipe, drain tile, fire brick and different grades of structural brick. They belong, for the most part, to the lower coal measures, a formation characterized by great abundance of argillaceous material. The upper division covering southwestern Iowa, also contains clay shales of similar quality. They occur in beds from a few feet to nearly one hundred feet thick, and are found generally distributed throughout the formation.

It happens that all of the known heavier beds which occurwithin the limits of Montgomery lie almost invariably at a considerable distance below the surface. Just over the limestone ledge which rests on the coal of the northeastern quarter of the county there occurs a bed of light grey or "blue" shale which is decidedly argillaceous and plastic. Its extreme thickness is about one hundred feet. This amount was shown at Briscoe, in Adams county, three or four miles east of the northeast corner of Montgomery. Here ninety-two feet of this "shell soapstone" was passed through in putting down the new Miller shaft, and it is not improbable that prior to the glacial erosion, this thickness was considerably in excess of what is now presented. The drift detritus now rests directly upon the shale. Unfortunately no railroad line passes across this immediate region. Transportation facilities are consequently meager; otherwise the eighteen-inch coal vein, once developed near Milford, would be again opened, and the overlying shale would be put to a number of economic uses. At present, none- 
of the heavier clays, those employed for making pavers and other strong articles, are utilized at any point in southwestern Iowa, northwestern Missouri or eastern Nebraska. The field for trade is great, while there is a strong demand, competition in the sale of the greater number of clay products is not close. Recent excavations along the river at Villisca has shown the existence there of several shale beds, some of which are quite suitable for the manufacture of the ordinary products. One or two of the beds at this point abound in calcite fossils which render the deposits valueless. In addition to the beds mentioned it may be important to notice the few bands and layers of argillaceous materials found separating limestone ledges. Near Stennett these thinner clay strata are very common in occurrence. The thickness of the individual beds range from a few inches to several feet, but in no place is the quantity sufficient to make the deposit of any particular use.

The presence of iron pyrites in crystal form, disseminated throughout the body of the shale bed, is not so common in the upper division as nearer the base of the coal measures. Pyrites, however, appear in small quantities, and there are also hard concretions of calcareous substances, but neither of these impurities occur to such an extent as to make the use of the clays in manufacturing unadvisable or to make the product poor, or unprofitable. The sinking of the shafts to such depths as would be necessary to reach workable coal measure shales, would not be advisable nor should the mining of the ordinary deep clays be undertaken unless in connection with the working of a coal seam.

ARENACEOUS DEPOSITS.

The arenaceous beds of the coal measures in Montgomery county are of little consequence, since true sandstone appears above surface at no point and sustains no well defined position in the borings. Where reported the sandstone was soft, sometimes micaceous and more or less clayey. The appearance of the hard siliceous beds of the Missouri stage was marked but once in the records of any of the deep drill holes put down at Red Oak, Villisca or any of the country localities. 


\section{CRETACEOUS.}

In reviewing the structure of the county White* set down as Cretaceous certain sandstones found along the East Nishnabotna, and placed the southern boundary of these beds at the county seat, Red 0ak. Only sandstones, or friable grits, were at that time referred to the Cretaceous, and other beds found exposed were left unclassified. It is now possible, however, to extend the formation so as to cover a large portion of the district, southward as well as eastward, into Page and Adams counties respectively. The existence of these sandstones in Montgomery county west of the East Nishnabotna can not be affirmed with certainty, as no exposures of the measures appear within these limits. Just over the line in the northeastern corner of Mills county there are outcrops, and within Montgomery the records of drillings indicate the existence of the Cretaceous over the coal measures in the uplands both west and east of the Nishnabotna. In brief, the Cretaceous may be said to lie immediately beneath the glacial covering over almost the entire highlands of the area. It would in only a few instances extend to and make up the bed rock of some of the larger streams, as these have almost invariably cut through the soft sandstone down into the harder upper Carboniferous strata.

NISHNABOTNA SANDSTONE.

(DAKOTA?)

Extent.-To certain arenaceous deposits in southwestern Iowa White gave the name Nishnabotna sandstone. This sandstone is best developed along or near the East Nishnabotna river. These arenaceous beds were the only deposits of the region that were recognized as Cretaceous.

Cretaceous outliers have also been found in other counties to the north and northeast. These are doubtless of the same age as those in Montgomery county and were probably at one time connected not only with one another, but also with the beds along the Nishnabotna river. The Mills and Pottawattamie outliers are therefore but areas isolated from the general deposit through erosion.

\footnotetext{
* Geol. of Iowa, Vol, I, p. 363.1870.
} 
In addition to the friable sandstones in Montgomery county there are beds of an entirely different character which are now classed as Cretaceous. There appears at the top of the formation a pudding-stone conglomerate which is prominent, but less persistent than the nearly homogeneous sandrock. The micaceous and the clean clay shales, so well exposed at Red 0ak, are evidently Cretaceous in age.

White took the deposit of brown massive sandstone southeast of Lewis, Cass county, as the rock presenting the typical features of the Nishnabotna sandstone. While no doubt a part of the formation, in lithological character, it is very unlike the formation at other points, being darker in color and more thoroughly indurated. False-bedding prominent in the beds elsewhere is not a feature of the Lewis rock.

Age.-The conclusion that these sandstones are of Cretaceous age is supported by Meek's discovery of leaves and imprints in the rock at Red $0 \mathrm{ak}^{*}$, and by the finding of similar impressions in the development of the quarries at Lewis.

A comparison of the lithology of the Lewis stone with that of the formation at Ellsworth county, Kansas, reveals the facts that the rocks in the two states are very nearly related if not of the same horizon. The Kansas locality furnishes numerous fossil leaves and many are of the same species as those present in the beds of southwestern Iowa. The Kansas rocks have been provisionally referred to the Dakota formation.

In Iowa the formation hitherto recognized as Dakota is exposed mainly in the vicinity of Sioux City. It consists of hard impure sandstone interbedded with irregular and usually heavy bands of argillaceous shales. Some of the sandstone layers are divided into shapeless ferruginous masses and these commonly contain plant remains. Lower in the measures more friable and shaly layers also contain poorly preserved specimens of leaves.

The shales at Red Oak, to which reference will subsequently be made, may be taken as the only known extensive deposit of Cretaceous clays within thissection of Iowa. Calvin thas explained

*Am. Jour. Scl, (2), vol. XLlV, p. 119. 1867.

†Iowa Geol. Surv., I, First Ana. Rep., pp. 17i-148. 1833. 
how the several divisions of the Cretaceous in Woodbury and Plymouth counties became deposited in a manner contemporaneously, and carrying out this theory Keyes in reviewing the geological formations of Iowa, says: "If the Nishnabotna is Cretaceous it may be the equivalent either of the Woodbury shales (Benton and Dakota) or of the Niobrara chalk." Lithologically the Nishnabotna is entirely unlike the Niobrara nor does it resemble the nearest known Benton. Its affinities, lithologically, are with the Dakota. Like the Dakota it is a marginal deposit and may have been laid down along the shore while either the Benton or the Niobrara were accumulating in the deeper parts of the Cretaceous sea.

The Cretaceous outliers are neither more persistent nor more extensive along the East Nishnabotna than along the several forks of the Raccoon. Since, however, the name Nishnabotna sandstone has already been applied, it does not seem advisable to change it until the correlation above suggested is verified, or until definite specific relations can be fixed.

The general character of the Cretaceons formation is displayed in figure 53, which was taken at the bluff just east of Coburg, at the south line of the county. The general crossbedded character is presented and over the softer fine grained and pebbly sandstones the hard ferruginous pudding-stone stands out in some relief.

DESCRIPTION OF TYPICAL SECTIONS.

Sherman Tonnship.-About half way between Elliott and Stennett, perhaps one hundred yards east of the Red Oak-Griswold branch of the Chicago, Burlington \& Quincy railroad, lies one of the most northern exposures of Cretaceous in Montgomery county. This is the abandoned Crandall quarry. In taking out the limestone it was necessary to remove a small amount of stripping, and in doing so several feet of weathered sandstone, doubtless Cretaceous, were exposed. This exposure was perhaps thirty feet above the river to the east. The principal outcrop, however, in this neighborhood is in the central portion of section 26 about one and one-half miles south of the Crandall quarry. The following section is shown. 


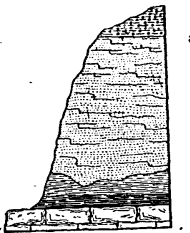

5. Drift........................... 5

4. Sandstone (...................... 20

3. Shale, bituminous, coaly below 34

2. Limestone, impure, earthy .... 2

1. Limestone, hard.

4

8

Figure 50. Upper Carbonifer-

ous and Cretaceous at Stennett.

Number 4, of this section is of Cretaceous age. It is a soft, slightly coherent sandstone, orange to white in color. Numbers 1,2 and 3 belong to the upper coal measures. Number 1 is partly exposed, extending beneath the surface of the water. Not more than fifty feet or so up Pilot branch the Cretaceous sandstone is thirty feet thick extending even below the level of the water. The Carboniferous beds do not here appear, indicating the deposition of the sandrock at this point in an eroded channel or in a depression in the coal measures. The sandstone is found outcropping along Pilot branch, perhaps a third of a mile. Beyond that point it is concealed by debris.

Near the top of the ridge, about one mile southeastward from the branch outcrop is located the Miller well, 223 feet deep. After passing through 117 feet of loess and boulder clay, Cretaceous sandstone was penetrated and found to extend to the bottom of the drilling. Between the point where the well is situated and the southern boundary of the township, beds of Cretaceous from five to forty feet thick appear. They consist of sands partly indurated, and in these are found lenticular pockets of very pure light grey or drab clays. They are especially noticeable a few feet above the stream near by. The pockets vary from two to ten inches in perpendicular diameter and are commonly less than eighteen inches in horizontal extent. Contact between the sandstone and the underlying coal measures is shown only at the point just mentioned. 
Near the southwest corner of section 13 of Sherman township, at the Powell spring, there is a bed of soft, light-colored sandstone exposed for a thickness of fifteen feet. The top of the sandstone is doubtless a considerable distance above but is concealed by drift debris.

Red Oak Township.-Sandstone such as noted in the southern potrion of Sherman township can be traced southward into section 2 , Ne. qr., E. $\frac{1}{2}$. At this point the height of the bluff is perhaps forty feet. White describes* a bed of clay at the base of the sandstone which likewise is probably Cretaceous, but at present. this material is not uncovered.

At Red Oak and in its immediate vicinity the development of Cretaceous beds is quite extensive and the variety exhibited here is greater than at any other point. Towards the summit of the hills within the town the deposits, as shown in street grades, consist almost exclusively of bright yellow clays, very arenaceous. In the cut along the Chicago, Burlington \& Quincy railroad in the southeastern portion of the town there are ten feet of rather fine light greyish to chrome yellow in color, partially indurated sandstone. Just above this on the slope, for a height of nearly one hundred feet, the same soft, sandrock was found; but at this point it contains numerous clay shale pockets of varying dimensions. These have been excavated and the clay utilized in the manufacture of pottery. On the lower side of the railroad, beds of argillaceous shale with a total thickness of from three to eight feet are displayed. Sandstone is interstratified in the upper portion, while under the clay there is a more thoroughly indurated sand deposit.

Further eastward along the railroad in the southwest corner of section 27 there are incoherent Cretaceous sands associated with which are one or two layers of pebbles. The figure here given represents the several kinds of materials found here and at the clay bank of the Cook brick works situated just beyond the track to tho north.

Sandstone predominates in the section given, and at "sand spring" in the northern edge of section 33 an eighteen foot deposit of light colored cross-bedded sandstone is shown.

*FIrst and Second Ann. Rep. of State Geologist, p. 64. 1868. 
Along the roadside to the west large blocks of the dark stone often covering the Cretaceous in this county, occur well towards the top of the hill.
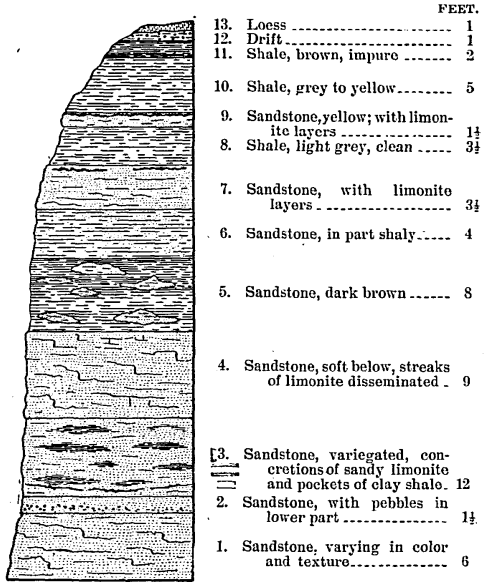

7. Sandstone, with limonite layers . ................... $3 \frac{1}{2}$

6. Sandstone, in part shaly ..... 4

5. Sandstone, dark brown ....... 8

4. Sandstone, soft below, streaks of limonite disseminated - 9

[3. Sandstone, variegated, con$\longrightarrow$ cretions of sandy limonite $=$ and pockets of clay shale. 12

2. Sandstone, with pebbles in lower part ................ 13

1. Sandstone, varying in color and texture................ 6

Figure 51. Vertical seetion through the Cretaceous at Red Oak.

Another outcrop is seen at the mill (sec. 32, Sw. qr., Ne. $\frac{1}{4}$ ) where the Cretaceous extends to low water mark and rests unconformably on hard coal measure strata. The Cretaceous beds, beginning with the lowest, are as follows: (1.) Eight feet of very micaceous, sandy, vari-colored shale; (2.) Micaceous, sandy shale with hard sandstone bands, thickness five feet; (3.) Six feet of impure, shaly, micaceous material more or less argillaceous; (4.) Seventeen feet of shaly clay, vari-colored, rather pure. 
Higher the measures are concealed by a few feet of driftabove which is loess partly exposed for some distance up the slope.

Grant Toonship.-About half a mile east of the Red 0ak and the Nebraska City branch of the Chicago, Burlington \& Quincy railroad (Tp. 71 N., R. XXXVIII W., sec. 17, Nw. qr., E.12) Cretaceous rocks are indicated by the contrast in topography. From this locality southward to the extreme southern boundary of Grant township the low land of the flood plain of the East Nishnabotna ends absolutely, and rather steep slopes, made up of Cretaceous beds, stand out prominently. The shallow ravines, elsewhere unimportant and few in number, are here sharper in cross-section and occur at frequent intervals. At the most northern point of this series of exposures the vertical extent displayed is about sixty feet. There is a deposit of fine buff to

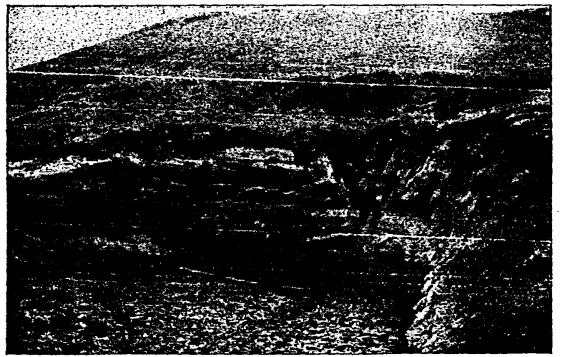

Figure 52. Cretaceous sandstone capped by pudding-stone.

white and yellow sandstone, quite fiable, thirty feet thick. Over this are twenty feet of a rather coarse and darker stone of similar character, but interbedded with it are thin bands of sand cemented by siliceous limonite. The upper division of the exposure consists of alternating layers of coarse sand and siliceous pebbles imbedded in a limonite or a siliceous clay 
matrix. The upper half is almost exclusively pebbles. The limit of the beds here is not disclosed, but the hill, at the foot of which the exposure stands out, rises perhaps sixty feet higher than the top of the outcrop itself, and it seems quite probable that the total thickness of the Cretaceous is almost one hundred feet. Deposits similar to the one just described are recognized southward for a distance of about three miles. The elevation of the outerops ranges from thirty to fifty feet above the valley. The hard pudding-stone which constitutes the topmost division, is disclosed, but the softer sandstone below is covered with washed materials.

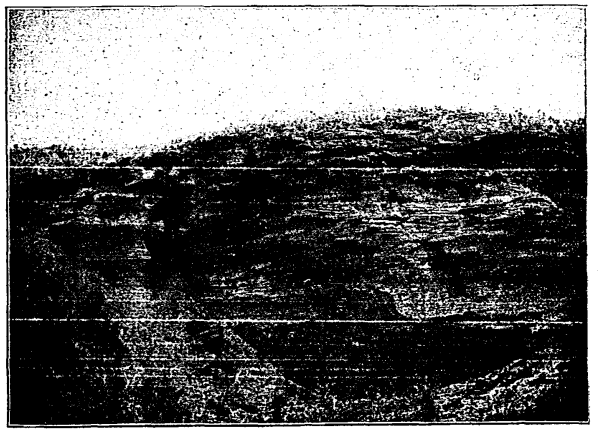

Figure 53. Typical exposure of the Cretaceous; Coburg, Montgomery county.

At Coburg, about 300 yards east of the track the combined section is às follows:

4. Conglomerate or pudding-stone with hard limonite and clays as matrix; thickness variable ........... 9

3. Gravel and sand in alternate cross-bedded layers ... 3

2. Gravel and sand - very coarse ........................ 2

1. Sand and gravel; light eolored; variably cross-bedded 18 
The bluff here is pictured in the accompanying figure 53 , the pudding-stone standing out in some relief in the upper portion.

Carboniferous limestone has been quarried about a quarter of a mile south of Coburg at an elevation of perhaps ten feet above the base of the section shown. About half way between this exposure and the location of that in section 17, a bed of very plastic red and grey shale clay, with a total exposed thickness of eight feet was developed, at the railroad grade. This bed corresponds with one along the track further north (sec. 32 , Sw. qr., Se. $\frac{1}{4}$ ) where there are nearly ten feet of red to brown more or less impure clays. The base of these clays is certainly not more than ten feet above the coal measure limestone which is exposed near the river at this point.

These Cretaceous clays constitute the impervious layer which determines the line of springs at the base of the sandstone. It seems, therefore, probable that while being decidedly variable, ranging in character from hard silico-micaceous shale to homogeneous, comparatively pure clay, that these shales are more widely distributed than has been supposed, and constitute the base of the Cretaceous throughout a large area of Montgomery county. Being heavily covered with drift their presence is rarely disclosed.

Exposures in this township remote from the East Nishnabotna are encountered at a number of points. In the northeastern quarter of section 20, along a fork of Ramp creek and a small branch entering this stream from the east, the outcrops consist of incoherent sands and fine gravels forming an extreme thickness of twelve feet. Along the south boundary line of the county, in the southeastern quarter of section 33, there appears a bed of massive light colored sandstone, twenty feet thick, which forms the bank of another fork of Ramp creek. On the hill to the north a well was sunk and this same rock was met at a depth of forty feet. This is at an elevation considerably above the top of the bank at the creek. Across in Page county there are outcrops on the slope several feet above the stream.

With one exception* the rocks here along the Page-Montgomery line represent the most southern known exposure of

-Proc. Iowa Acad. of Scl., vol. I, Part 1v., pp. 33-43. 1894. 
Cretaceous strata in Iowa. White placed the limit at Red Oak, but further investigation has resulted in finding the ferruginous pudding-stone, which in most instances marks the presence of the Cretaceous, south of Red Oak along the county road about one mile east of Essex.

Washington Tounship.-The only definitely recognized Cretaceous within this township lies near the center of section 21 , just southward of the West Nodaway, perhaps thirty feet above low water. It consists of soft sand deposits with a vertical exposure of only seven feet. In color it is yellow to dark brown. Loose fragments of very dark siliceous limonite, such as overlies the measures elsewhere in the county are not uncommon.

Above the branch in section 27, Sw. qr., Sw. $\frac{1}{1}$, there is shown a few feet of yellowish clay which is very plastic and contains but very little impurity. This clay is in all probability of Cretaceous age.

Across the county line in Adams county limited exposures of Cretaceous are exhibited along the roadside between sections 19 and 20 also 16 and 17 in township 72, range XXXV. In these localities the measures are recognized by the slabs of hard, brown, iron-stained sandstone and lighter shades of the softer rock of unknown thickness. The uplands between the West and Middle Nodaway in at least northeastern Montgomery county and northwestern Adams are for the most part underlain by the Cretaceous rocks. Heretofore they were not recognized south of the small outliers in the south-central portion of Cass county.

Between the exposures mentioned in the ricinity of the East Nishnabotna in the western half of Montgomery county, and those between the two Nodaways in the extreme western section, the actual existence of rocks of the same age is not commonly shown by natural exposures. There is one exception. It is located about eighteen feet above a small stream in Tp. 73 N., R. XXXVI W., sec. 29, Sw. qr., Ne. $\frac{1}{4}$. Here grey and red sandy clay and sand with disseminated siliceous limonite fragments, are displayed in an imperfect ontcrop. However, in the Rosacrantz prospect hole already mentioned, beds of 
Cretaceous sandstone were penetrated, and combining this fact with the conditions on all sides it is safe to assert that the district between the Nodaways is underlain by a considerable thickness of Cretaceous. Above it is the rather heavy covering of drift; below it is the upper Carboniferous.

\section{LITHOLOGICAL FEATURES.}

Reviewing the descriptions just detailed it will be seen that the general character of the deposits varies greatly at different stratigraphic levels. Even at the same level the characteristics are not persistent for any great horizontal distance.

Arenaceous Deposits.-The only rock at all similar to the brown stone which has been quarried near Lewis, occurs as a covering from one to fourteen inches thick over the lightcolored more friable sandstones. This mantle, however, is harder and more ferruginous than the quarry stone at Lewis. .In some instances it changes gradually into the lower stone, but ordinarily the thin covering weathers free. For the most part the Cretaceous of Montgomery is an arenaceous formation. Near Red Oak and at Coburg the sand beds are heterogeneous, certain layers being more or less pebbly. Here current bedding is a prominent feature. At the "sand spring" just south of Red Oak, the twelve foot exposure bears near its central portion a layer two feet thick which is decidedly cross-bedded, while above and below, the lines of deposition are nearly horiizontal. Towards Stennett the measures are much like the arenaceous deposits in the vicinity of Red Oak except that at Stennett the color is bright yellow to orange.

Conglomerate Materials.-From Red Oak southward to Coburg the most noticeable stone of Cretaceous age is the pudding-stone. Non-siliceous limonite is the cementing material. This conglomerate usually occurs in ledges from two to fifteen inches thick, and may or may not be false-bedded. At Coburg, also in the northwest quarter of section 17, two miles northward, this stone exhibits very marked cross-bedding, and under it lies the soft sandstone itself even more irregularly stratified.

Shale Bels.-The micaceous sandy shales which occur with very considerable thickness at the Keystone mill below the 
county seat, are the only beds of such character yet recognized south of the principal Iowa Cretaceous at and near Sioux City.

For a number of years the argillaceous seams at Red Oak have been utilized in the manufacture of clay products. In character these shales vary somewhat from the smooth, homogeneous, very plastic-not gummy, to the more siliceous beds locally known as fire clay. In this latter case the siliceous material is not commonly disseminated throughout the stratified clay beds, but appears as partings separating the nearly pure argillaceous bands. The silica occurs as microscopic grains. The pure clay is by no means gritless, but in the production of common pottery the silica is in such minute grains as not to be injurious. Other imperfectly exposed Cretaceous clays occur at two or three points along the track north of Coburg. They do not possess the shaly character of the Red Oak clays nor are they so free from ferruginous and arenaceous matter.

Lenticular masses of clays such as occur in the clay bank at Red 0ak, are found in smaller bodies disseminated through the soft sands in the banks of the stream in the northern edge of the town and in the southern part of Sherman township.

FLORA.

Remains of plants are very abundant in different beds of the Dakota at Sioux City and Sargent Bluff. Where best preserved the leaves lie in a dark red to brown ferruginous sandstone. Leaves have also been observed in the brown stone at Lewis. Reference has already been made to Meek's discovery of specimens of exogenous leaves in the sandstone at Red Oak. The beds in which these were discovered have not been worked for any purpose and no other record of the presence of vegetable remains has been made. The identity of the Cretaceous flora of Montgomery and Cass counties, with that of northwestern Iowa, and of Ellsworth county, Kansas, has already been suggested. From the very nature of the Dakota sandstone the complete preservation of delicate foliage could scarcely be expected. 
Fauna.

The Cretaceous formation of Montgomery county is marked by extravagant current-bedding characteristic of marginal deposits. Animal remains, if they occur at all, are likely to be found only in the finer argillaceous beds, but an examination of these beds at Red Oak has not resulted in the finding of any animal fossils whatever. In the pudding-stone formation near Coburg occasional fragments of coral, and now and then some other imperfect fossil species have been discovered. These, however, have no significance, since they were derived from the same source as the associated pebbles and have no relation to Cretaceous faunas.

TOTAL THICKNESS.

At the Milner well (Tp. 73 N., R. XXXVIII W., sec. 35, Ne.qr., Se. $\frac{1}{4}$ ) the Cretaceous was reached at 118 feet and extended to 223 feet beneath the surface. At that depth the measures were not completely passed through. Estimating the surface of the ground to be about two hundred feet above the bed of Pilot branch a short distance northward, it is evident that the coal measures would be reached but a few feet lower; making the vertical extent of the Cretaceous here about 115 feet.

Near Red Oak the total thickness is perhaps as great, but the beds are composed of different materials; sandstones, clays and micaceous sandy shales. Farther southward the contact of the Cretaceous with the underlying strata is not shown, but near Coburg and two miles northward the actually connected exposures are from thirty to sixty feet high. Beyond the top of the outcrops the hill rises to a considerable height. The extreme thickness at any selected locality may be placed at 125 feet and the total thickness of the measures within the county between 150 and 175 feet.

PLEISTOCENE.

The unconsolidated surface materials in Montgomery county are composed of the following: 1. Glacial deposits. 2. Loess. 3. Alluvium. These may all be included under Pleistocene. 
LOWER TILL.

The true glacial deposits of the county are referred to the lower till. Although decidedly variable in character, this formation may be separated into two general divisions, blue boulder clay and yellow boulder clay. The former lies unconformably upon the stratified beds of the Cretaceous or upper Carboniferous and is not commonly exposed. It cousists in the main, of a bluish grey clay. The upper part is a tough plastic variety, not very sandy yet bearing a percentage of both fine and coarse siliceous matter. It carries calcareous particles and concretions which vary in size from minute specks to irregular masses two or three inches across. The lower or more truly blue clay is homogeneous, and being siliceous lacks much of the plasticity common to that clay above it. Impurities such as lime are less abundant in the true blue clay. Exposures of this lower drift are by no means numerous. Occasionally, in excavations and in newly washed banks, a few feet of it are shown. The base of thelower till is made up of quicksand and fine gravels commonly free from argillaceous matter.

In the sinking or driving of shallow or surface wells, this purer clay is passed through and the underlying sand and gravel serve as the water-bearing strata. Water-worn boulders are distributed to some extent throughout the upper part of the blue till.

The common yellow drift clay overlies the blue division. It consists of a clay, yellow to green and brown in color, in which concretions of lime, pebbles and small boulders of siliceous rocks are freely disseminated. The texture of the yellow boulder clay is not unlike that of the lower blue clay except for the presence of pebbles and boulders. The boulders are mostly granites of varied hues. Schists, quartzite, diabase and other varieties of rock are not of uncommon occurrence.

Where but thinly covered the upper portion of the till has been modified by percolating waters until now the calcareous concretions have been dissolved and a partial or total disintegration of the contained granitic rocks has taken place. These altered deposits, besides being freed of much of their impurities 
become thinner and distinctly jointed, which latter structure is more evident as the clay becomes completely dried.

In addition to the regular yellow boulder clay there are in the till limited deposits of coarse sand, in part argillaceous and completely iron-stained. Surface boulders are by no means common. There are a few points, however, especially in the northwestern portion of the county, where the surface shows pebbles and small boulders. Again, at intervals along the principal drainage courses boulders several feet across are seen. These have fallen from corraded banks. In character these rocks are not unlike those contained in the regular boulder clays.

The total vertical extent of the drift is not brought out except in deep borings, and from these the variation in thickness is found to be considerable. In the southwestern part of Donglas township the depth to the Carboniferous rocks, as shown in the Rosacrantz and McCracken deep drillings amounted respectively to ninety and one hundred feet. This latter thickness was entirely of Pleistocene and only the upper twenty feet of the Rosacrantz was of the unconsolidated beds. In the Davis well (Tp. 72 N., R. XXXIX W., sec. 8, Sw. qr., Sw. 1) about three miles and a quarter northwest of Hawthorne, no stratified beds have been reached at 120 feet from the surface, and here all except the upper twenty feet consist of yellow and blue boulder clay, in part gravelly. It may be that in the highest points in Lincoln township the thickness of the drift mantle will prove to be in some cases more than 160 feet. In the edge of Cass county the boring of several wells proved the depth to the bottom of the till to range between 80 and 110 feet, with overlying loess usually not more than 15 feet.

In the central and southern tiers of townships the drift mantle has a thickness of from twenty to sixty feet. Where the coal measures occupy an unusally high position the covering is mainly of loess and is not more than ten feet thick. On the other hand a few localities in this portion of the county show drift extending to the surface. The irregular and unequal erosion of both the Carboniferous and Cretaceous beds has in turn left a corresponding roughness in the under surface 
of the drift. This, together with the varying thicknesses due to its own irregular deposition has resulted in the variation in the thickness of the till which is now so noticeable.

LOFSS.

For the greater part the entire upland of the county is covered with loess. The western boundary of Montgomery is approximately twenty-five miles east of the Missouri river, along which bluffs and knobs composed nearly entirely of loess rise to heights from 100 to 200 feet above the water level. However, this formation so heavy here, attenuates very rapidly eastward so that over Montgomery county its extreme thickness is perhaps thirty-five feet and its average scarcely more than four or five feet. Over limited areas there is a marked absence of true loess. In other rather broad stretches it is altered to such a degree that it is impossible definitely to place the line of contact with the under till. In character the formation is variable. The heavier deposits have lost some of the features which characterize typical loess. The color is nearly similar, but its texture has been so altered that instead of the massive, porous variety there is commonly a jointed more plastic clay. The homogeneity of any particular division is retained. Throughout the great loess bed of western Iowa and elsewhere hard lime concretions, known as loess-kindchen, are disseminated in patches at irregular intervals. If such ever existed in the deposit in Montgomery county they have been dissolved out by percolating waters. Loess shells, so abundant in the heavy beds, are not known to be present in Montgomery county.

ALLUVIUS.

Valleys with widths varying from a few yards to nearly two miles border the East Nishnabotna, the West and Middle Nodaway rivers, and the Middle Tarkio and Walnut creeks. These constitute the flood plain area of the county. The larger streams flow in the wider valleys. A distinction between the first and second bottoms has already been made. The former is more properly an alluvial deposit. Superficially it consists of a grey to black silty material which grades downward 
into a mixture of siliceous clay and sands. The so-called second bottom extends from the most recent flood plains to the base of the hills. The upper fifteen inches are perceptibly colored by decayed vegetable matter.

The make-up of the lower portion of the second bottom is disclosed in dug wells and along the streams. Its constitution is not constant. Evidently the materials originated in part from the Cretaceous measures, severed and redeposited without any great breaking up of the mass and in part from a redeposition of the till and loess which has washed from the slopes. The thickness of the alluvial deposits varies somewhat with the irregularities in the surface upon which the washed materials were laid down. The upper surface is usually nearly smooth with slope sufficient for ample drainage. Next to some of the smaller water courses the alluvial fields are in disconnected patches first on one side then on the other side of the channel.

\section{ECONOMIC PRODUCTS.}

BUILDING STONES.

Notwithstanding the fact that exposures of hard rock in Montgomery county are quite rare and confined to certain comparatively limited fields, rock suitable for ordinary másonry is abundant. The quarry industry is one of no mean importance. The Upper Carboniferous, the Cretaceous and the Pleistocene are productive of rock for building purposes. In order of importance these beds are as follows: limestone, sandstone, conglomerate or pudding-stone and glacial boulders.

\section{LIMESTONE.}

Quarrying in the rocks of the Upper Carboniferous bas been prosecuted here for more than a quarter of a century. The first work was done just north of what is now the town of Stennett. Since then other quarries have been opened in this vicinity on the west as well as on the east side of the Nishnabotna and the total amount of stone taken out and utilized has been great. The limestone occurs in ledges from a few inches to more than three feet thick. As a rule it is durable and 
readily adapted to use in massive masonry and for all common purposes. Many of the beds are susceptible of a fine finish.

The W. Stennett quarry lies at the point of the hill near the Red 0ak and Griswold line of the Chicago, Burlington \& Quincy railroad, just above the mouth of Pilot branch. Layers nearly on a level with the waters of the East Nishnabotna, west of the track, have been developed.

The section on page 392 shows the workable and worthless beds, as well as the amount of stripping. At present this stripping would include all material above number $S$ of the section, but as the work is pushed farther into the hill ledges of limestone now thoroughly weathered will become solid and of value. At the same time the thickness of the refuse material increases. The breadth of the quarry is not more than forty feet. A single derrick has been in use.

The C. B. \& Q. Ry. quarry lies at the opposite side of Pilot branch and shows the same ledges of stone as those worked at the Stennett quarry. This quarry has not been worked for three or four years. Stone has been quarried at Crandall, about a mile and a half north of Stennett, and quarrying has also been done at a point the same distance south of the station. The upper ledges shown at the Stennett quarries were developed in both cases.

The Fate quarry is an old quarry situated on the west side of the river in the northeast corner of the southeast quarter of section 22, Sherman township. The face is nearly 100 feet in length. Until recently the fall section as described on page 392 was opened and the numerous ledges utilized for various purposes. At the present time the three ledges shown are the only ones worked. The uppermost undivided ledge is tyventy inches thick. It is finely sub-crystalline and slightly fossiliferous. The other two are also heavy ledges, the upper one being fourteen and the lower twenty-four inches thick. The stripping here, including the shale and impure rock between the beds, amounts to more than ten feet. The stone is all used for dimension work and takes a ready finish. One derrick is used in loading the stone. 
The Rosebury quarry is on the south side of a small stream (Tp. 73 N., R. XXXVIII W., sec. 21, Se. qr., Se. $\frac{1}{4}$ ) and has a lineal face of about 120 feet. The following is the section:

9. Soil, loess and drift...................... FEET. INCHES.

8. Limestone, sub-crystalline, brittle; good dimension stone .........................

7. Shale, buff to grey ...........................

6. Limestone, soft, flinty in upper three-

5. Limestone, sub-crystalline; foundation and dimension stone......................... 7

4. Limestone bearing many specimens of Fusulinze and much chert................ 4

3. Limestone with Fusulinæe and some calcite

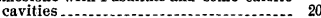

2. Limestone, yellow, earthy; crowded with

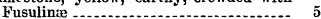

1. Limestone, abounding in Fusuline and dark flint......................................

21

34

14

7

4

The Ladd quarry is in the bluff west of the river (Tp. $73 \mathrm{~N}$., R. XXXVIII W., sec. 27, Ne. qr., Sw. $\frac{1}{4}$ ). Work in this quarry has not been carried on since the season of 1892 . The sequence of strata which includes the quarried ledges is here given:

6. Decomposed limestone and clays FEET. INCHES.

5. Limestone, abounding in Fusulinæ........-. 110

4. Limestone, same as No. 5, but also flinty... $\quad 10$

3. Limestone, earthy; decomposed in part.... $3 \quad 36$

2. Limestone, blue; sub-crystalline; dimen-
sion rock......................................

1. Limestone, light grey, many Fusulinæ and
light grey flint (exposed)

The $\mathrm{H}$. Rush quarry is also on the west side of the river (Tp. 73 N., R. XXXVIII W., sec. 27, Ne. qr., Ne. $\frac{1}{4}$ ) a short distance northward from the Ladd quarry. Here several ledges were worked, the greater number of which can be found in Fate quarry. The beds presented are:

FEET. INCHES.

5. Limestone, hard, sub-crystalline; dimension stone

4. Shale, argillaceous, buff to greenish...... 3 , 4

3. Limestone, impure ocherous................ 1 2

2. Limestone, semi-crystalline, light colored; dimension stone..................... 1

1. Limestone, hard, light color; dimension stone $\ldots . . . . . . . . . . . . . . . . . . . . . . . .2$ 
The S. Stennett quarry is one recently opened on the east slope of the hill (Tp. 73 N., R. XXXVIII W., sec. 22, Se. qr., Se. 1) perhaps thirty feet above the river. Thus far only the three principal ledges of the Fate quarry, as now worked, have been developed. A considerable quantity of stone has been removed from the same ledges in other small quarries in sections 22 and 27.

The new Clark quarry is situated about a mile west of the East Nishnabotna ('Tp. 73 N., R. XXXVIII W., sec. 33, Se. qr., Nw. $\frac{1}{4}$ ). The face of this quarry as now developed is about 150 feet long. The following shows the sequence of strata:

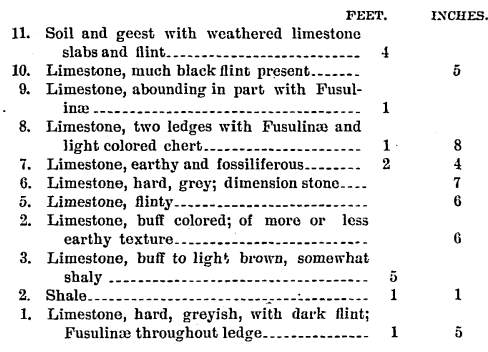

The abandoned Clark quarry lies about a quarter of a mile northward. The dip, if any, is imperceptible.

The McCalla quarry ('Tp. 73 N., R. XXXVIII W., sec. 33, Sw. qr., Sè. 1) lies about a quarter of a mile southwest of the new Clark quarry. It is crescent shaped, quarrying being done on either side of a shallow ravine. The thickness of the waste material is not great, and several ledges of stone are available; as shown in the accompanying section:

\begin{tabular}{|c|c|c|}
\hline \multicolumn{2}{|c|}{ FEET. } & \multirow[t]{2}{*}{ INCHES } \\
\hline 13. Soil & 1 & \\
\hline 12. Limestone, decomposed, Fusulinse bearing- & 1 & 6 \\
\hline 11. Clay, for the most part residual ................ & 1 & 4 \\
\hline
\end{tabular}




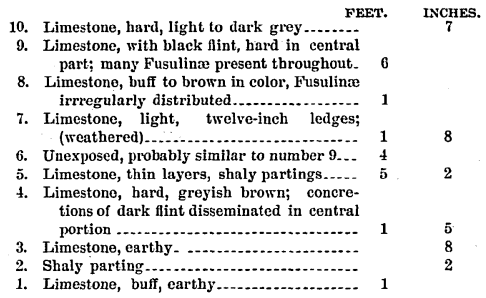

Further development will doubtless result in bringing to light workable ledges in numbers 5 and 6 . The divisions are now badly weathered.

The Silket quarry is on Walnut creek in Tp. $72 \mathrm{~N}$., R. XXXIX W., sec. 1, Ne. qr., N. $\frac{1}{3}$. At this point the most important beds lie in the bed of the creek. The combined section is:

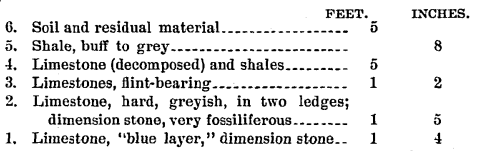

A short distance from this opening on the low slope on the east side of Walnut creek several ledges of limestone have been worked.

The next quarry along Walnut Creek is at Climax (Tp. 71 N., R. XXXIX W., sec. 30, Ne. qr.) At this point the following section was secured:

7. Soil, loess and drift............... FEET

6. Limestone, hard, drab, finely textured; not fully exposed.

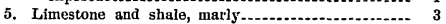

4. Shale, argillaceous, grey $\ldots$

3. Limestone, bluish, dull, earthy ................... I

2. Shale, argillaceous, grey .................................. 1

1. Limestone, light blue, hard; dimension stone........ $1 \frac{1}{\frac{1}{2}}$ 
Since the covering is heavy it is not probable that quarrying, other than for local use, will at any time be done here. Up to this time no large amount of stone has been removed.

The supply of building stone in the southern portion of the county is obtained partly in Montgomery county and partly in Page. There are three or four quarries in the latter county within a distance of a few miles from the south line of Montgomery. The Gridley quarry is just across the line. The Nelson limestone quarry (Tp. 71 N., R.XXXVII W., sec. 20, Nw. qr., Ne. $\frac{1}{4}$ ) lies in the bed of a small tributary of Middle Tarlio. It bas been opened but a year or two, and since that time has been worked to supply the local demand and the demand at Stanton.

But two ledges of stone are utilized. The lower one is a foot thick. It is a hard, greyish blue limestone bearing disseminated particles of iron pyrites often changed to the hydrous oxide. On account of this impurity the stone would be slightly inferior for outside walls. Between this bed and the upper bed there are about six inches of marly shale. The top ledgea yellowish grey, more or less earthy limestone, is also one foot thick. The output from this quarry is used largely as foundations, and as undressed dimension stone.

The abandoned Johnson quarry is in the N. $\frac{1}{3}$, Sw. qr., sec. 20, Tp. 71 N., R. XXXVII W. On the other side of the branch, and southward a few hundred feet, is the old Jacobson quarry. Across the Tarkio near the southeast corner of section 20, is the deserted Lantz quarry. The stone at all of these places is but the continuation of the strata at the Nelson quarry.

Northward, about half way between the Lantz quarry and Stanton, a few perch of stone areannually taken from the slope some distance above Middle Tarkio. East of Villisca, about a mile and a half, limestone has been obtained and used for flagging and for cellar walls. This quarry is on a small branch near the main line of the Chicago, Burlington \& Quincy railroad. There being but one bed of particular value and it covered by several feet of clay shale, but a small amount of work has ever been done to open up the quarry. 
The northeastern township is well supplied with a superior building stone, but located as the quarries are, ten miles or more from any railroad, the annual output from this section of the county is comparatively small. Only a local demand can be economically met.

The Smith quarry is in Ne. $\frac{1}{4}$, Sw. qr., sec. 3, Tp. 73 N., R. XXXVI W., extending non-continuously for a distance of perhaps 600 feet along the west hillside. At the north end the following section was secured:

\begin{tabular}{|c|c|c|}
\hline FE & & INCHES. \\
\hline Soil, loess and residuary clay................... & 3 & 10 \\
\hline $\begin{array}{l}\text { Limestone, weathered, with geest in erev- } \\
\text { ices ... }\end{array}$ & 5 & \\
\hline Limestone, light grey, sub-crystalline, finty & 1 & 8 \\
\hline 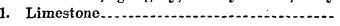 & 1 & \\
\hline
\end{tabular}

Toward the southern part the worked face of the section is somewhat different. Across the West Nodaway, possibly 100 yards west of the Smith quarry, is the one known as the Fisher. The following beds are exposed:

FEET. INCHES.

3. Limestone, shaly ............................. 1

2. Clay, shale, grey to yellow..................... 2 2 4

1. Limestone, flinty in upper part, bear Fusulina (solia ledge exposed) ................ 3

The stone in the vicinity of Milford is commonly a rather coarsely textured variety, hard but easily dressed. In color the light greyish-brown prevails. Between the two quarries mentioned and the milldam at Milford, where much stone has been taken out, there is another exposure of limestone, presenting three layers. Each is about two feet thick, and over the beds are nearly twelve feet of stripping. This place, and the Smith and the Fisher quarries, have furnished a great amount of stone for dimension work, for buildings and for the construction of the Milford dam. It is a very tough, durable stone which does not fracture in cold weather, nor shell off upon continued exposure.

In the edge of Cass, at the very extreme northeast corner of Montgomery county, there are two rather extensive quarries, 
the Phelps and the Fox, respectively on the west and east sides of the county road. The strata exposed at the one is also shown at the other, except that the Fox has been worked to a greater depth. Only those above number $\tilde{j}$ in the section here inserted are disclosed in the Phelps. The individual layers are as follows:

\begin{tabular}{|c|c|c|c|}
\hline 13. & & & INCHES \\
\hline 3. & Soil, limestone slabs and residual clay.... & 2 & \\
\hline 12. & Shale, argillaceous, greenish. & 4 & \\
\hline 11. & Limestone, light colored (one ledge)....... & 2 & 6 \\
\hline 10. & Limestone, light grey to buff........ & 1 & 1 \\
\hline 9. & Clay, marly & 1 & \\
\hline 8. & $\begin{array}{l}\text { Limestone, sub-erystalline, greyish to } \\
\text { brown led from nine to fourteen inches }\end{array}$ & & \\
\hline 7. & $\begin{array}{l}\text { brown ledges from nine to fourteen inehes } \\
\text { Shale }\end{array}$ & $i$ & $\begin{array}{l}1 \\
4\end{array}$ \\
\hline 6. & $\begin{array}{l}\text { Limestone, brownish, sub-crystalline to } \\
\text { dull }\end{array}$ & 1 & 2 \\
\hline 5. & Shale, bituminous in lower portion... & 1 & 6 \\
\hline 4. & Limestone, coarsely textured & & 9 \\
\hline 3. & Shale, buff to grey; fossiliferous ......... & 1 & 4 \\
\hline 2. & $\begin{array}{l}\text { Shale, variegated, earbonaceous near bot- } \\
\text { tom }\end{array}$ & 2 & I \\
\hline 1. & Limestone (exposed) & 1 & \\
\hline
\end{tabular}

These quarries are so situated as to supply stone for Adams, Cass and Montgomery counties. A number of the ledges are successfully used in heavy masonry; blocks of almost any desired dimension can be obtained. The stone is not difficult to dress. It is certainly unfortunate that better transportation facilities from such quarries as these in Montgomery and across the line in Cass are not at hand.

In addition to the quarries already mentioned, there are a number of places where limestone has been taken out. On account of the great depth of stripping and the inaccessibility of the ledges, work was but temporary. The ravine south of Red Oak below the Keystone mill, at Clark mill, a quarter of a mile southeast of Coburg, southward from Hawthorne in the bed of Walnut creek, and in the edge of Page county ('I'p. 70 N., R. XXXVIII W., sec. 4) are the more common localities. In most cases but one or two ledges are accessible.

SANDSTONE.

Within the limits of the county the coal measure sandrock is entirely absent. The only arenaceous beds which might 
serve as structural material belong to the Cretaceous, representing the Nishnabotna sandstone. About Red Oak near Stennett, also in the southeast quarter of section 35 of Sherman township, the northeast quarter of section 2 of Red 0ak township, there is a dark to light brown sandrock from two inches to more than three feet thick overlying the friable, light colored stone. It is hard enough in many places to serve for foundation and rough construction work. In part this stone is not unlike that at the quarries southwest of Lewis, Cass county, where a large amount has been removed and utilized for the erection of houses, foundations and chimneys. Only occasionally has any of this stone been quarried in Montgomery, the thickness being usually insufficient and the color of the stone undesirable.

CONGLOMERATES.

The Cretaceous pudding-stone occurs on the steep slopes east of the river, almost continuously from three miles south of Red Oak to within three-fourths of a mile north of the southern boundary of the county. The maximum thickness of the bed is not definitely shown but the average is approximately twenty-five feet.

The Chicago, Burlington \& Quincy railroad company has opened up the Cretaceous conglomerates in the east half of the northwest quarter of section 17, Grant township, and has quarried a great amount of the material for ballast. Here the beds are firmly cemented by siliceous limonite, but in the lower portion they are of loose pebbles and coarse sand. No work has been done in this place in the last few years. Just east of Coburg the lower portion of this conglomerate is exposed and the layers have been used to a small extent for foundations. A few hundred feet up the small branch from the southeast corner of Red 0ak there is another bed of loose pebbles in coarse sand which might be used advantageously as ballast.

GLacial BoUlders.

Being generally concealed by the loess, the drift debris furnishes but an inappreciable quantity of available rock which would be at all suitable for dimension stone. In the southern half of the county there is seen an occasional boulder several 
feet across. In the northern part there are patches of uncovered glacial deposits which afford material valuable as rough foundation stone.

\section{CLAYS AND THEIR USES.}

The quality and the very general distribution of clays suitable for the manufacture of various grades of building bricks and for drain tile, make this material of primary economic importance in Montgomery county. Throughout the district, with only a few exceptions, it is possible to find superficial deposits having depths of from two to twenty feet, of such constituency as to be readily worked into marketable products. In order of importance on account of adaptability and prevalence the clays may be classed as follows: (1) Loess; (2) Cretaceous shales; (3) Alluvium; (4) Coal measure shales; (5) Boulder clay.

\section{LOESS.}

The loess is quite generally distributed. It occurs as the mantle of the upland over nearly the entire area. In thickness it is variable, and in character it may be divided into the two more common forms-that found on the slopes and welldrained sections, and that on the level prairie. 'The former is a brownish-colored, homogeneous material resembling in great part the deposit where typical along the Missouri bluffs to the west, bearing hard, calcareous concretions. The prairie loess is of a greyish yellow to brownish color, decidedly more plastic than the other and containing no detrimental impurities. These clays are such that good brick or tile can be manufactured from either, but on account of the excessively elastic or "stronger" nature of the prairie deposit, much trouble will be experienced in attempts to avoid cracking while the brick, especially, are being dried. A combination of the two varieties or the introduction of shale clay or sharp sand into this strong loess will largely lessen the amount of checking.

Methods for handling these clays depend primarily of course upon their nature, but almost any of the deposits can be moulded by hand, by the wet-mud, by the stiff-mud or by the dry-press processes. In this county the use of the loess alone 
has been attempted at but one factory and the two last named methods are practiced. At some of the larger factories, however, very successful results are obtained by combining the loess in various proportions with the clays of the Cretaceous. Regardless of the kind of process the treatment to which these clays are subjected is the most simple and the products are successful and durable, invariably possessing a desirable color.

CRETACEOUS SHALES.

While not occurring abundantly in more than one or two localities Cretaceous shales are of such a character as to be adaptable to use in clay plants in the manufacture of many kinds of products. Under the description of the lithological character of the Cretaceous, mention has been made of the several localities supplied with argillaceous materials of that age, so but a brief reference to these will be inserted. Of the clay under the soft sandstone (Tp. 72 N., R. XXXVIII W., sec. 2, Ne. qr.) White* says: "A bed of clay is found which is a mixture of a dark and ochery clay with that of nearly white color. The latter has been tested for the manufacture of common pottery and pronounced to be the best found in the southwestern part of the state." The only clay of such description now exposed in this neighborhood lies in pockets or lenticular beds, and in quantities too small to be of any value.

Along the railroad track, about two miles northward from Coburg, beds of grey and of red arenaceous clays are visible. These might be utilized if not overlain by such heary stripping. The beds at Red Oak are by far the most important. They are extensive, conveniently situated, and are quite pure. The presence of clay in this neighborhood was ascertained through outcroppings well toward the top of the hill above the present pit. The raw material was first secured from numerous pockets which were found to contain very limited amounts of a first class clay, and soon the supply became exhausted. Careful prospecting, however, led to the discovery of a large deposit, the upper surface of which extends almost as high as the railroad track to the south. The shale shows the effects of erosion,

-First and Second Ann. Rept. of the State Geologist, p. 64. 1868. 
deep gorges having been corraded, and the uppermost portion being mixed with a reldish loess. Eastward the clays are intermingled with arenaceous blocks and masses of siliceous limonite. The adaptabilities of this shale in its purest state are hardly limited. It has been made into common stock and fire brick, sidewalk blocks, drain tile and pottery. It is easily prepared. Brick are successfully made by the dry-press or by the stiff-mud machine. Ordinarily the shale burns to a cream color, but when combined with ferruginous clay different shades of red are secured.

ALLUviuM.

The alluvial deposits of the county occur only along the larger water courses. The upper two or three feet only are available, unless a special treatment is given, and this is hardly practicable. In the immediate vicinity of the rivers traversing the county the alluvial deposits are of a loamy character for a depth of several feet, and in this case the entire thickness of the material can be made into common brick, using the hand presses for moulding.

\section{COAL MEASURE SHALES.}

Unlike the lower, or Des Moines stage, the upper coal measures, or Missouri stage, does not present many heavy beds of argillaceous shales. Yet between the solid ledges of limestone in various sections of Montgomery county there exist layers of good workable shales from two to eight feet in thickness. Around Stennett the quarries exhibit such beds, one of the most noticeable being shown resting on the top ledge of limestone in plate xi. Along the branch, about a mile and a half east of Villisca, a similar bed is visible. South of Red Oak the exposures are imperfect. Recent excavations disclose several shale beds at Villisca, some of which are quite valuable. Others bear calcareous fossils and are not so successfully utilized.

On the cap-rock over the coal vein which occurs in the northeastern portion of the county there rests a shale several feet thick, and under the coal is an impure fire clay, two or three feet thick, which changes to ordinary shale lower down. 
These beds do not appear exposed at convenient points, but since the vein of coal averages only about eighteen inches it is necessary to remove a portion of either the under or the overlying strata. These accompanying argillaceous materials are suitable for draintile, paving and common brick, and also, in some cases, for sewer-pipe and fire brick. The establishment of clay plants in connection with the coal mines could be made profitable. In some localities in the state this plan is followed very successfully, even where the removal of the shale is not necessary in order to mine the coal. As yet no attempts have been made to extensively utilize the shales of southwestern Iowa. Experiments have been carried far enough to demonstrate their utility.

\section{BOULDER CLAY.}

The drift although bearing extensive argillaceous beds, is neither a convenient nor a profitable source of workable clays, partly on account of the overlying deposit of loess and partly on account of the concretions of lime which abound in the upper, or yellow, boulder clay. These concretions are very injurious to the burned product. It may be possible to find limited areas of altered drift which have been freed from this impurity by percolating water.

\section{PAINT AND BALLAST CLAYS.}

About a quarter of a century ago a plant was established for the production of mineral paint from an ocherous shale, and a considerable quantity was marketed. The expense incurred in preparing, and in transporting the product to shipping points made the undertaking unprofitable, and work ceased. The bank is now entirely covered by over washed soil. At Milford in the sinking of a well, the occurrence of an eight-foot bed of ocher was reported at forty feet from the surface. In all likelibood this is an ordinary vari-colored coal measure shale, and is not valuable as a base for paint.

In the construction of railroads the use of burnt clay as ballast is fast becoming popular. In the altered loess and drift, and in the more gumbo-like areas of the bottoms, material might be selected suitable for the manufacture of this 
product. Ballast burning was carried on for some time at Red Oak nearly fifteen years ago, and much of the burnt clay was used along the line of the Chicago, Burlington \& Quincy railroad.

\section{CLAY INDUSTIRIES.}

Three of the principal towns of Montgomery county are supplied with plants utilizing native clay in the production of structural brick, drain tile and other articles.

RED OAK.

The W. H. Close Pottery, Brick and 'Tile Works is located near the central portion of Red Oak. The nucleus of this concern was formed more than twenty years ago, but until 1883 attention was devoted entirely to the manufacture of pottery. Included in the list of articles now produced are front or stock brick, .common brick, fire brick, sidewalk blocks, draintile from two and a half to eight inches in diameter, and all styles and sizes of ware commonly made at modern potteries. The plant consists of necessary sheds, including those for drying the green ware a Bond dry-press, "The Ohio" of E. M. Freese \& Company a Wolfe \& Conley continuous, and six common down draft kilns, two being used in burning the pottery, a Frost dry pan and a clay chaser. Until so extensively enlarged two years ago only a Penfield plunger and the turning wheels with the chaser now used, made up the list of machinery.

The clay is all hauled about half a mile from down near the railroad track. That used for fire brick and pottery is of Cretaceous age. The more siliceous, when properly burned, produces a good refractory article. For tile, common, stock brick, and sidewalk blocks, either loess alone, or loess combined with the more impure Cretaceous shale is found most satisfactory. The admixture of the shale is productive of a lighter colored article, depending of course upon the relative amounts of shale and the strong dark brown to nearly red loess, which itself burns to a cherry red color.

The appearance of the cut while partially hidden by debris is shown in figure 54. The shale at some points is as much as fifteen feet thick and rests unconformably upon a very siliceous 
shale of the same age. At the east end it is replaced by friable sandstones, and higher up, perhaps three or four feet above the upper surface of the shale, yellowish sandstone is shown in the

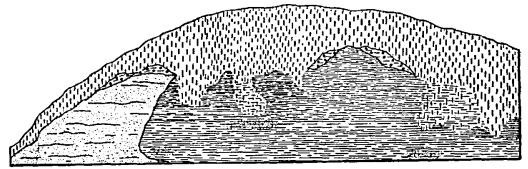

Figure 54. Cross-section of the Close clay pit, Red Oak.

railroad cut. The extreme thickness of workable shale in the portion of the clay bed at present developed is given in the following section; number 11 showing theaverage thickness of the overlying loess:

\begin{tabular}{|c|c|c|c|}
\hline & & & No \\
\hline 11 & rtio & 6 & 6 \\
\hline 10. & Sandstone, light yellow, soft.. & 3 & \\
\hline 9. & Shale, light grey; used for pottery. & & 11 \\
\hline 8. & Sandstone, white to yellow............ & 1 & 6 \\
\hline 7. & Shale, light grey; for pottery........ & 2 & \\
\hline 6. & Shale, grey, siliceous; for fire brick. & 1 & 1 \\
\hline 5. & Shale, dark to light grey; for pottery..... & 1 & 6 \\
\hline 4 & Shale, grey, siliceous; for fire brick...... & & 2 \\
\hline 3. & Shale, light to dark grey; for pottery ..... & 2 & 2 \\
\hline & Shale, greyish; for fire briek......... & & 6 \\
\hline & liceous, & & \\
\hline
\end{tabular}

The individual layers of the purest clays, those made into pottery, are constant throughout in texture and composition. The accompanying chemical analysis, made by Prof. G. E. Patrick, best shows the nature of the deposit.

PER CENT.

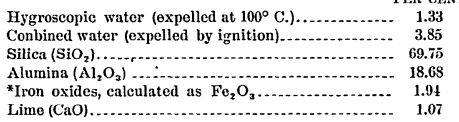

-Hostly protoxides; an approximate determination gave: $\mathrm{FeO}, 1.22 ; \mathrm{Fe}_{2} \mathrm{O}_{3}, .58$ Thls gires a summation of 100.35; error in antaly'sis, .39. 


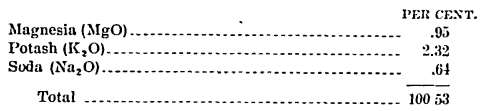

It will be noticed that the percentages are not perceptibly different from clays used at many Ohio, Kentucky, Indiana and other factories, the alumina being comparatively a little less. The clay is of such a character that, when moulded by the drypress, burning must be accomplished with much care until the water has been entirely removed. To burn every section in the continuous kiln at one time from three to five weeks are previously consumed in water-smoking. This kiln has a capacity of 500,000 brick.

The fire brick are moulded on the Boyd press. They require a high heat to prevent crumbling. It is quite probable that this clay when washed could be made into a superior quality of glass pots and crucibles. In burning the pottery a very high heat is withstood before the slightest "crippling" takes place.

The raw material was at first taken from small pockets well up the slope from the track, but as these became exhausted search for new beds was necessary and this resulted in the finding of the bank now worked which to all appearances is inexhaustible.

The R. E. Cook brickyard is situated just north of the Chicago, Burlington \& Quincy railroad at the southeastern corner of Red Oak. Work was begun here several years ago and has since been carried on quite satisfactorily. The equipment consists of an $\mathrm{H}$. Brewer roller crusher, a Kells \& Sons brick and tile machine, dry sheds, two clamp and one common round down draft kilns.

The clay is obtained from two adjoining cuts at the side of the plant. The upper one is circular with perhaps 200 feet of lineal face. The material here consists of twelve feet of ordinary loess. This rests upon three or four feet made up of mixed Cretaceous clays, boulder clay and loess. At the other pit the following sequence is seen: 


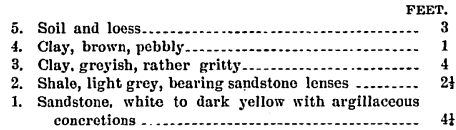

The layers as indicated in the section are by no means persistent in different portions of the worked cut. From the drillings of a well bored here it is observed that shales with interstratified sandstone layers extend to some depth.

Although made up of a rather complicated variety of clays some of them decidedly impure and siliceous, the product, common building brick, is in no wise inferior. The brick have a good color and the mode of manufacture is entirely efficient.

viLLISCA.

Stoddard Brothers brickyard, operated by Smith \& Coffin, is in the southern portion of Villisca. Here brickmaking has been carried on for ten years, always by hand until 1894, when a secondhand Frey-Sheckler stiff-mud machine was put in. The clay up to that time was a "bottom" clay from along the Middle Nodaway. Its thickness was from six to ten feet. The upper part is silty. That below the clay worked appears to be almost wholly derived from the loess, and portions of the material are somewhat jointed. Since the machinery was put in loess has been used. The quality of the clay is quite good, but the brick when drying crack badly in the sheds.

Recently a coal measure shale has been discovered which can be mined advantageously with the loess, and the cracking is thereby lessened. The beds now shown above the water are:

5. Loess, yellow to brown or grey, jointed in upper

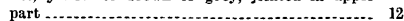

4. Sand, clean; thickness varies from one inch to...... 2

3. Shale, argillaceous, dark grey to green in color.... 4

2. Shale, argillaceous, light grey ...................... 3

1. Shale, grey to light, rather finely siliceous................

Number 5 is a fine grade of clean loess strictly adaptable to use in the dry-press. Number $\mathbf{3}$ is quite pure and of good 
quality, although the shrinkage upon burning will be considerable. Number 2 is for the most part a superior shale but is very fossiliferous, bearing both thin shells and crinoid stems, which latter are wholly calcite and become caustic when burned in the clay; otherwise this layer would be valuable for common uses. Number 1 is not fully exposed, but borings in the neighborhood are said to show it to be from twenty to sixty feet thick. Except for its being a little too arenaceous it is readily available for many purposes. It is now possible to. utilize the loess and some of these shales and secure a superior building brick. The manufacture of pavers from the shales would be practicable but for the presence of the deleterious crinoid stems.

The Tyler brickyard is in the southern part of Villisca and east of the Middle Nodaway. It has been in operation five years. It is a small plant, the equipment consisting of a Quaker soft-mud machine, horse power. The clay bank is five or six feet deep and consists in the upper portion of a siliceous silt bearing a considerable percentage of humus. This grades into a brownish arenaceous clay locally known as "made earth." At the base of the cut joint clay sets in, and eighteen feet from the surface a bed of quicksand is encountered. T'emporary kilns, holding from 80,000 to 135,000 brick, are used in burning. Some trouble is experienced in the cracking of the green product.

\section{STANTON.}

Nelson Sandin has a brickyard in the western part of Stanton along the banks of Middle Tarkio. The clay is a loamy material taken from the flood plain. Its thickness is variable, In some portions the so-called joint clay extends to within one or two feet of the surface. Ordinarily, however, it is possible to use the material to a depth of seven feet. It is found that, by the addition of common salt to the extent of six quarts to mud enough for 5,000 brick, the amount of checking during the drying process is greatly reduced. Cased kilns are used in burning. The consumption of the product is almost wholly local. The brick are rather porous and are therefore only used. for interior construction work. 
SAND.

Although containing little or no free sand in the beds and - overflowed banks of the large streams, Montgomery county is well supplied with arenaceous deposits. They occur both in the Cretaceous and in the till. Those of the former abound wherever the formation exists. Near Red Oak and southward as far as Coburg, the prevailing color is nearly white. Near Stennett and to the east the sands are orange to yellow. The sandstone is fine grained except for a small percentage of coarse material in individual layers. The grains are more or less rounded but not so much so as in the drift sands. On account of the size and comparative sharpness of the grains the material is suitable for mason work and for use in brick moulds. The slight percentage of oxide of iron which it contains prevents its use in the manufacture of glass. However, it may possibly be utilized in moulds at smelters.

South of Milford (Tp. 73 N., R. XXXVI W., sec. 22, Sw. qr., W. $\frac{1}{2}$ ) there is a high knob capped by loose sand and resembling an ordinary river deposit. For the most part the sand is quite clean and somewhat sharp. Its thickness is probably not less than fifty feet. Another deposit of similar character lios on the slope about one mile eastward from Villisca. This and the one near Milford are used by plasterers. The Villisca material is also used by the brick manufacturers to sand the moulds. Other localities furnish sand beds of economic value.

COAL.

Westrope Slope--Since 1881 no mining of coal within the limits of MLontgomery county has been undertaken. For several preceding winters, even as far back as 1857 , mining was quite extensively carried on at the Westrope slope (Tp. $73 \mathrm{~N}$., R. XXXVI W. sec. 1, Se. qr., W. 1). The vein was found outcropping several feet above Williams branch. Its thickness was from eighteen to twenty-two inches. The sequence of beds is shown in figure 48 , page 403 .

Anderson Prospect Shaft.-Coal was reported at a depth of fifty-five feet in a drilled hole (Tp. 72 N., R. XXXVI W., sec. 33, Ne. qr., Se. 1) four and one-half miles north of Villisca. The 
seam was said to be twenty-two inches thick. A shaft sunk with a view to mining the coal failed to reveal the presence of the stratum, and further search has not since taken place. It is not improbable that the Nodaway vein would be found at no great depth in this vicinity, though it may have been cut out by erosion.

A well just south of the Westrope slope disclosed the presence of the Nodaway coal, and just east of the boundary of Montgomery county (Tp. 73 N., R. XXXV W., sec. 1S, Sw. qr.) it was again met with in digging a well. The record given below is said to be accurate:

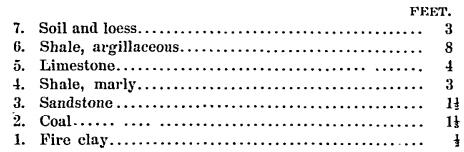

The coal mentioned in the different localities is the same vein as is worked so successfully at Briscoe, Carbon and Eureka in Adams county, at New Market and along the East Nodaway six miles northward, in Taylor county, southeast of Clarinda, near Shambaugh, in Page county. Along Middle Tarkio, southeast of Nyman, there has been a small development. Reference has been made to the extent of the vein. It seems to underlie, within available distances, nearly the entire northeastern third of Montgomery county, excepting perhaps certain localities in which erosion has been exceptionally deep. The indications are that westward the coal vein dips to too great depths to be of value. When coal was first removed from the Westrope slope the price was fifteen cents per bushel. Now it is usually from three to five cents less, though still great enough to make the mining of the vein profitable when near enough the surface. Facts brought out by the deep drilling and by a study of the exposed formations of Montgomery and adjoining counties, inevitably lead to the conclusion that only thinner seams such as already have been met with need be looked for. This conclusion is opposed to that heretofore 
entertained, namely, that the lower measures would, when reached in southwestern Iowa, be equally as productive as in the central and southeastern portions of the state where the Des Moines division is exposed at the surface.

LIME.

The manufacture of lime in this district has never been undertaken except on a very small scale. Where the limestones are more abundantly exposed about Stennett and at Milford, as well as in the southern portion of the county along the Tarkio, a very fine quality of lime might be produced. The better ledges of the stone bear but a low percentage of silica or alkalies, the more common constituents which detract from the value of lime. The stone would produce a white lime, but one which would only be used for ordinary mortar or plaster, not being strong enough and being too readily affected by moisture for the better class of work.

\section{ROAD MATERIALS.}

The native substances which might be used advantageously for road beds are: limestones, clays, drift boulders, gravels and sands. As yet neither the streets of the larger towns nor the roads of the interior have been paved. The limestone, being as a rule hard, would make an excellent macadam. It would also serve as a basis for brick paving and as ballast for railroad beds. Mention has already been made to the use of burnt clay as ballast, and its use might be extended to the construction of county roads. Being comparatively inexpensive it will doubtless yet be used in districts not abundantly supplied with gravel. 'The preparation of the clay is very simple. In the upper portion of the Cretaceous, between Coburg and Red Oak, the conglomerates and loose sandy and pebbly layers are quite accessible and could be made available. The drift deposits, which are made up for the most part of coarse sand and large pebbles, when not overlain by clays, might also be used for similar purposes.

SOIL.

Within Montgomery county three distinct varieties of soil are present. These are the loessal, the alluvial and the glacial. The area bearing the first named is by far the greatest 
as practically the entire upland prairie and the hillsides are covered by it. 'I'he soil proper, that is the dark grey colored, humusbearing material, is commonly only a foot or two in thickness, but the loess from which this soil is directly derived has a thickness in some instances of as . much as thirty feet. In character this loess, which acts as subsoil, is soft, more or less spongy and calcareous; it admits of easy infiltration of water in excessively wet weather. In case of drouths it readily gives up moisture by capillary attraction and furnishes a lasting supply to the growing crops. When altered the subsoil is more plastic and clay-like. 'This loess soil is the most productive variety within this part of Iowa.

'True alluvial soils are naturally confined to the flood plains. The second bottom is not subject to overflows and the soil is more compact than that of the lower lands. These soils are all very siliceous and bear a considerable percentage of decayed vegatation in the upper portion, becoming more clayey below. Under ordinary circumstances they are remarkably fertile. The till where occupying the superior position in a few very limited areas, mostly in the northwest quarter of the county, could not properly be termed arable. It consists in the main of boulders a few inches in diameter and of sandy clay. 'There are also a few patches of Cretaceous land north of Coburg, which are of little or no value from a productive standpoint.

\section{MINERALS.}

Calcite, pyrite, limonite, hæmatite, and perhaps other rarer minerals occur in Montgomery county, but none in quantity sufficient to make them of economic importance. 'The calcite occurs in the form of crystals lining cavities in some of the ledges of limestone near Milford, and more rarely elsewhere. Pyrite is observed in the stone of the Nelson quarry and in the coal. Limonite occurs in the Cretaceous, but is very siliceous. A few hæmatite boulders were discovered in the surface drift.

WATER SUPPLY AND' WATER POWERS.

The inhabitants of Montgomery county secure their water supply from several sources. T'he streams form the most 32 G Rep 
important one. The two larger water courses which traverse the entire length of the county and the Middle Nodaway in the southeastern portion, are never failing sources. The Tarkio, Walnut and Indian creeks are streams which in ordinary seasons are not dry, except well toward their sources. 'I'he drift deposit affords much water, and in this formation there are many veins which are practically inexhaustible. The water commonly lies in a series of pockets of sand or gravel between the yellow and blue boulder clay. These sand pockets are not persistent, nor is water invariably secured at this horizon, but failures are exceptional. In the flood plains it is nearly always practicable to go down from twenty to fifty feet, or a little below the level of the water in the stream, and strike a lasting supply. Red Oak and Villisca obtain their water supply from wells dug in the flood plains of the adjacent rivers.

Springs issuing from the upper coal measures have not been seen in the county, neither do borings in the strata, unless at great depths, show the presence of flowing veins. At the foot of the Cretaceous sands, probably flowing over shales, fine springs which never run dry pour forth large volumes of clear cold water. Notable instances of these are in Tp. 71 N., R. XXXVIII W., sec. 17, Nw. qr., E. $\frac{1}{2}$, north of Coburg, at "sand springs" just south of Red Oak, in the northern portion of section 33, also in Tp. 73 N., R. XXXVIII W., sec. 13, Sw. qr., Sw. $\frac{1}{4}$ on the old Powell farm.

The rivers which act as unfailing water supplies may also furnish power. Ordinarily the declivity is not great but is sufficient to produce considerable fall. By the proper construction of dams power for various manufacturing purposes may easily be developed. Good locations are frequent as the channels proper are usually rather narrow and are bounded on one side or the other by a bank of limestone.

Along the Nishnabotna there are three mills utilizing water power; a grist mill a mile north of Stennett, Clark \& Company's mill in Tp. 72 N., R. XXXVIII W., sec. 8, Se. cor. and the Keystone mill just south of Red Oak ('Ip. 72 N., R. XXXVIII W., sec. 32, Sw. qr., Ne. 1). At each of these points the river flows against stratified beds. 
On West Nodaway there are the Smith mill at Milford, or Grant P. 0., the Morton in the southern portion of section 33, Douglas township, and the Arlington in Tp. $72 \mathrm{~N}$., R. XXXVI W., sec. 28, Nw. qr., Se. $\frac{1}{4}$. On Middle Nodaway, near the center of section 11 of Jackson township, is located the J. Van Horn mill. At Climax in the extreme southeastern part of the county a mill was once established. This was dependent upon the water of Walnut creek for power. It was found that the stream became too low in dry weather and milling at this point has been abandoned. 


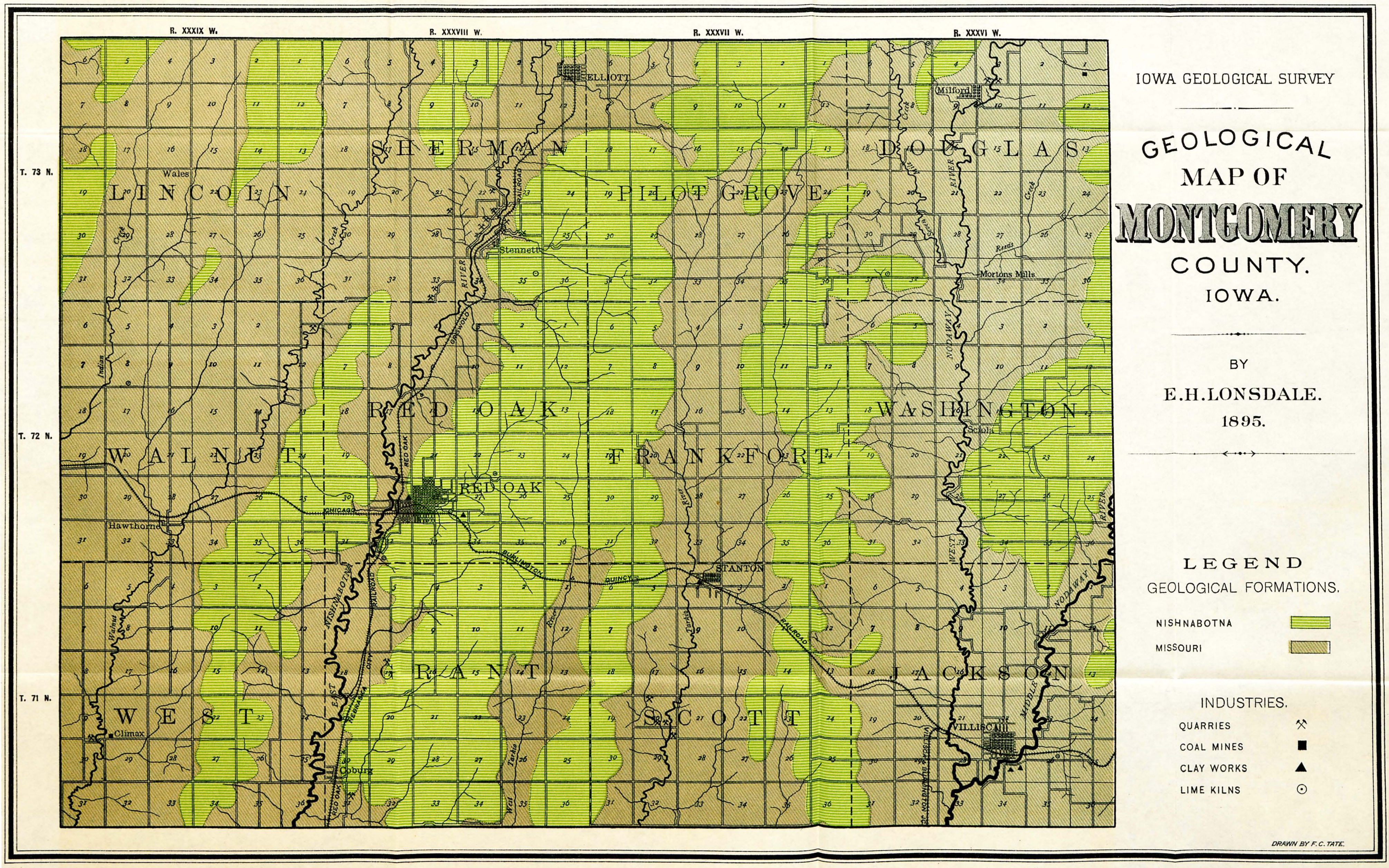


